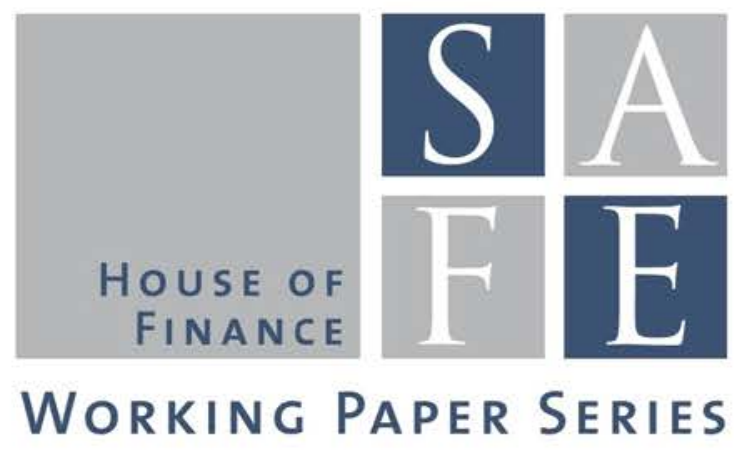

Silvia Dalla Fontana - Marco Holz auf der Heide - Loriana Pelizzon Martin Scheicher

\title{
The Anatomy of the Euro Area Interest Rate Swap Market
}

SAFE Working Paper No. 255

SAFE I Sustainable Architecture for Finance in Europe A cooperation of the Center for Financial Studies and Goethe University Frankfurt 


\title{
The Anatomy of the euro area Interest Rate Swap Market* $^{*}$
}

\author{
Silvia Dalla Fontana \\ USI Lugano - Swiss Finance Institute \\ Marco Holz auf der Heide \\ European Central Bank \\ Loriana Pelizzon \\ SAFE - Goethe University Frankfurt \\ Martin Scheicher \\ European Central Bank
}

This version: June 2019

\begin{abstract}
Using a novel regulatory dataset of fully identified derivatives transactions, this paper provides the first comprehensive analysis of the structure of the euro area interest rate swap (IRS) market after the start of the mandatory clearing obligation. Our dataset contains 1.7 million bilateral IRS transactions of banks and non-banks. Our key results are as follows: 1) The euro area IRS market is highly standardised and concentrated around the group of the G16 Dealers but also around a significant group of core "intermediaries" (and major CCPs). 2) Banks are active in all segments of the IRS euro market, whereas non-banks are often specialised. 3) When using relative net exposures as a proxy for the "flow of risk" in the IRS market, we find that risk absorption takes place in the core as well as the periphery of the network but in absolute terms the risk absorption is largely at the core. 4) Among the Basel III capital and liquidity ratios, the leverage ratio plays a key role in determining a bank's IRS trading activity.

Keywords: OTC derivatives, network analysis, interest rate risk, banking, risk management, hedging;

JEL Classification: G21, E43, E44

${ }^{*}$ The views presented in the paper are those of the authors only and do not necessarily represent the views of the the European Central Bank, the SSM or the Eurosystem. The authors thank Christian Resch for research assistance. Loriana Pelizzon thanks the Research Center SAFE, funded by the State of Hesse Initiative for Research (LOEWE), for financial sponsorship. Contact authors: silvia.dalla.fontana@usi.ch; marco.holz.auf.der.heide@ecb.europa.eu; pelizzon@safe.uni-frankfurt.de; martin.scheicher@ecb.europa.eu
\end{abstract}




\section{Introduction}

This paper analyses the structure of the OTC euro area IRS market. For this purpose, we make use of a novel and proprietary set of transaction data. The IRS market represents the largest segment of the OTC derivatives market, accounting for more than $60 \%$ of the global OTC derivatives market (Bank for International Settlements (2017)). The euro area IRS market has an aggregate gross notional of EUR 98.3 trillion, which means that the notional volume of our dataset equals $37 \%$ of the global market volumg 1 . At the time of writing, IRSs in the EU are mostly traded OTC (i.e., in bilateral transactions between major financial firms). In contrast, in the US, "Swap Execution Facilities" have been playing an important role in the trading and in particular in the price formation of many derivatives categories for quite some time.

Due to the private nature of bilateral transactions, OTC derivatives markets are "dark markets"(Duffie (2012)). Their systemic importance has been clearly illustrated in the global financial crisis. In the process of post-crisis regulatory reforms, reducing the opacity and fragmentation in OTC markets has been a priority for global policy makers (cf. Financial Stability Board (2017)). For the definition and implementation of these policy goals, understanding the OTC market structure and activity is an essential ingredient. The aim of this paper is to help policy makers and academics to better understand the structure of this important fixed-income market.

Bilateral trading has historically made analysis of the IRS market structure difficult as there was a general lack of comprehensive transaction data. However, since the global financial crisis, the Dodd-Frank Wall Street Reform and Consumer Protection Act in the US and the European Market Infrastructure Regulation (EMIR) are addressing opacity, counterparty risk and contagion risk. Two key elements of these regulatory reforms illustrate the relevance of our analysis of the anatomy of the euro area IRS market: (i) most standardised OTC derivatives are now being centrally cleared and (ii) OTC derivatives transactions are being reported to "trade repositories"(TRs). More specifically, since 2016, transactions in the EU in basis, fixed-to-float IRS, FRAs, and OIS in EUR, GBP, JPY and USD have to be centrally cleared. Hence, all new trades in standardised IRSs are now being cleared via Central Counterparties (CCPs). The second element of the new framework is specifically targeted to improve post-trade transparency by means of making transaction data

\footnotetext{
${ }^{1}$ See Bank for International Settlements (2017)
} 
available to supervisors and central banks. We are therefore able to use a novel regulatory dataset of bilateral OTC euro area IRS transactions defined by the EMIR regulation (see Abad, Aldasoro, Aymanns, D’Errico, Fache Rousová, Hoffman, Langfield, Neychev, and Roukny (2016) for a detailed introduction to the dataset). Our sample comprises around 1.7 million IRS transactions among 55,643 counterparties. Out of these more than 55,000 counterparties in our sample, we fully identify and categorize the major 282 major entities, which account for $95 \%$ of the overall notional exposure. The gross notional volume of our data set equals around EUR 98 trillion, hence, we cover $37 \%$ of the global IRD market ${ }^{2}$ (assuming no double counting) and more than $98 \%$ of the EUR market ${ }^{3}$. Our unique transaction dataset allows us to investigate the market microstructure and the dynamics of IRS trading in the euro area starting from individual transactions up to a sectoral and finally a market-wide perspective.

Our paper can also shed some light on the potential impact of the leverage ratio requirements on the OTC derivatives market. Basel III has introduced capital and liquidity requirements on top of the risk-weighted capital requirements already present in Basel II. In particular, via the leverage ratio, Basel III requires banks to hold capital against certain types of off-balance-sheet exposures for derivatives with a risk weight of $100 \%$. We empirically investigate the relevance of this policy issue in the euro area IRS market. We study whether Basel III capital and liquidity ratios influence the gross and net trading activity in IRS trades. The IRS market is of particular relevance as it is characterized by high gross notionals and these notionals directly influence the level of the leverage ratio. Therefore, this market is particularly suitable for investigating how the introduction of the leverage ratio has affected market activity in key segments of the OTC market. In the context of IRS trading, one key ingredient is the punitive treatment of high notional-long maturity positions which are commonly used by Pension Funds and therefore require a bank to the opposite position. Boyarchenko, Eisenbach, Gupta, Shachar, and Van Tasse (2018) discuss that post-crisis regulation not only affected the targeted banks directly but also impacted asset managers who require active bank intermediation for their trading strategies. They analyse arbitrage opportunities between US Treasuries and USD interest rate swaps, finding that the regulatory treatment of IRS exposures reduces the total return on such relative value trades (including also cost of bank capital). Therefore,

\footnotetext{
${ }^{2}$ See BIS Statistics: http://stats.bis.org/statx/srs/table/d5.1

${ }^{3}$ Estimate from cleaned data set based on ECB Statistical Data Warehouse
} 
lack of "balance sheet space" can prolong potential mispricing across a range of market segments. The main goal of our paper is to document stylized facts on a key derivatives market. Our findings can then be used for extending the theoretical work. We test a number of hypotheses derived from the existing empirical and theoretical literature on OTC markets. We offer three main contributions to the empirical literature on OTC markets.

- First, we describe the structure and trading activity in the Euro area IRS market. Our analysis considers both the aggregated level (defined as total gross and net notional volume aggregated across all instruments) as well as key subsegments of the market. We define market subsegments by means of currency (e.g., activity in EUR versus USD) or maturity (e.g. activity in 10-year swaps versus 5-year swaps). So far, a detailed description of the largest segment of the OTC derivatives market has not been available.

- Second, we investigate specialization among IRS traders. In particular, we compare the strategies of dealers, major banks, and non-banks in terms of their activity across currencies and maturities. We investigate differences in terms of their gross or net notional exposure. We distinguish determinants of gross and net trading activity. Hence, we also study the "flow" of interest rate risk in the network.

- Third, we investigate how a trader's IRS activity is related to its balance sheet. We focus on banks due to availability of comparable balance-sheet data. We test whether bank characteristics such as bank size or Basel III capital (both using risk weights and leverage ratio) and liquidity ratios explain differences in trading activity.

Our key empirical results are as follows: We observe that trading in the IRS market is focused on standardized instruments and concentrated around a group of core banks (and major CCPs). In contrast to the network of other OTC markets (e.g., CDS), the core of the market (defined by bilateral notional exposures) is not only composed of G-16 Dealers (i.e., banks with material investment bank activity), but also some universal banks ("intermediaries", in our terminology), which make active use of IRSs in a range of currencies and maturities, whereas they typically do not actively participate with similar intensity in, for example, CDS trading. We also find that the portfolios of non-banks are more specialised than most banks' IRS portfolios. Finally, we observe that net risk exposure is significantly allocated both in the core as well as the periphery of the 
network. In terms of banks' balance-sheet characteristics, we find that dealers' and intermediaries' large trading activity is not just driven by their balance-sheet size, but that other variables matter as well. Moreover, we find that a bank's leverage ratio determines the size of its trading activity as well as its net notional exposure. Banks having similar characteristics, in presence of lower leverage constraints, are more active in the IRS market. The other two Basel III ratios that we consider (risk-weighted capital ratio or proxy for liquidity ratio) are instead not relevant.

Overall, our findings shed new light on the current structure of OTC trading and the impact of regulatory reforms. We significantly extend previous empirical analysis 4 , which was typically focused on just two groups of traders: dealers, who trade with all market participants, and customers, who only trade with dealers (cf. Collin-Dufresne, Junge, and Trolle (2019) for US index CDS and Getmansky, Girardi, and Lewis (2016) and Bellia, Panzica, Pelizzon, and Peltonen (2017) for the single-name CDS market). However, this binary categorization does not capture market activity in the largest segment of the OTC derivative market: the IRS market. An additional driver of the more complex structure of the core of the IRS market is the rapid growth of central clearing. All in all, the core of the euro area IRS market therefore consists of dealers, other major universal banks, and CCPs.

So far, despite its magnitude and economic importance, few papers have studied the IRS market. The overwhelming majority of empirical papers has concentrated on the CDS market 5 . Fiedor, Lapschies, and Orszaghova (2017) perform a network analysis of the EU's centrally cleared interest rate derivatives market, with a focus on counterparty relations within both direct (house) clearing and client clearing. Benos, Payne, and Vasios (2016) study the links between centralized trading, transparency, and the US IRS market liquidity. They present evidence from the implementation of the Dodd-Frank Act on USD IRS. Hoffmann, Langfield, Pierobon, and Vuillemey (2017) focus on total interest rate exposures and match IRS exposure to balance-sheet exposures to interest rate risk. Cenedese, Ranaldo, and Vasios (2019) study pricing differences between transactions using central and bilateral trades, focusing on the non-mandatory clearing period. We are largely complementary to these papers since we focus on a period wherein central clearing is mandatory and

\footnotetext{
${ }^{4}$ See Duffie, Garleanu, and Pedersen (2005) and Duffie, Garleanu, and Pedersen (2007) for research on theoretical frameworks

5 Oehmke and Zawadowski (2016) provide the first detailed anatomy of the CDS market. See also Collin-Dufresne et al. (2019), Loon and Zhong (2014), Loon and Zhong (2016), Arora, Gandhi, and Longstaff (2012), Battiston, D'Errico, Scheicher, and Peltonen (2018), and Brunnermeier, Clerc, and Scheicher (2013)
} 
look at (i) the role the different traders' categories and (ii) the potential role of capital requirements constraints are playing in this market in terms of gross and net notional exposures.

The rest of this paper is organized as follows. Section 2 provides some background on the IRS market and the regulatory framework. Section 3 introduces our research issues and empirical hypotheses. In Section 4, we describe our dataset. Section 5 presents our results, starting with the descriptive statistics for our novel dataset, both at transaction and trader level, and then we test the different hypotheses described in Section 3. Section 6 concludes.

\section{Background}

In this section, we briefly describe the mechanics of IRS and important recent changes in the regulatory framework for OTC derivatives trading.

An IRS is an agreement to exchange cash flows at specified points in time according to a bilateral contract (cf. Chapter 7 in Hull (2014)). Credit institutions, institutional investors, or industrial firms use IRS to adjust differently structured payment flows in asset-liability management, to hedge against interest rate risks or to take on such risks for trading purposes.

In the euro area, the Euribor unsecured money market rate is currently typically used as the underlying interest rate, while the Libor rate is used for GBP or USD transactions. These reference rates have a maturity of three or six months and the maturity of the corresponding swaps is typically five or ten years. Banks specifically use IRS for hedging interest rate risk in their loan books or bond portfolios, transforming the cash flows from bond issuance or intermediation (i.e., providing hedging opportunities for other banks or non-financials).

A common economic mechanism behind an IRS position is the comparative advantage that each side of the transaction holds in a particular market segment. At the initiation of a transaction, the present value of the position of the fixed rate payer corresponds to that of the floating rate payer. The spread between the current floating rate and the initially determined fixed rate is typically re-calculated at half-year intervals. Depending on whether the calculated spread is positive or negative, one or the other counterparty will have to pay the incremental cash flow At the initiation of the transaction the market value of a standard IRS is usually very close to zero (cf. Hull 2014). During the lifetime IRS are often valued as the difference between the value of a fixed-rate bond 
and the value of a floating-rate bond where the floating rate bond is priced by noting that it is worth par immediately after the next payment date.

In the aftermath of the financial crisis, global regulators have put in place a number of measures to foster the resilience of the OTC market (cf. Financial Stability Board (2017)). Among recent regulatory developments, three measures deserve particular attention in the context of IRS analysis:

- Clearing obligation: EMIR includes the obligation to centrally clear certain classes of OTC derivatives via authorised CCPs 6 . Since February 2016, EU transactions of major market participants in basis, fixed-to-float IRS, FRAs, and OIS in EUR, GBP, JPY, and USD have to be centrally cleared. Hence, all new trades involving "standardised"IRS among dealers and major banks are now cleared via CCPs, whereas for instance, Pension Funds can for the time being still use bilateral clearing.

- Mandatory margining: EMIR also fosters risk mitigation in non-centrally cleared OTC contracts. Bilaterally cleared transactions have to be covered by margining, covering both current ("variation margin") as well as the potential future exposure ("initial margin"). This reform came into force for the major dealers in February 2017. This second element of the revised regulatory framework focuses on the bilateral market because EMIR also foresees detailed requirements for CCP risk management

- Post-trade transparency: According to Article 9 of the EMIR, the counterparties of a derivative contract have to report the details of the transaction, including modifications and cancellations to a trade repository (TR), "no later than the business day following the conclusion, modification or termination of the contract". The set of details shall be reported to a TR registered according to Article 55 title VI or recognized in accordance with Article 77 of the EMIR.

CCPs have been active for a long time in the clearing of exchange-traded instruments such as stocks or derivatives which often use a central order book. However, the contagion in the aftermath of the Lehman collapse in September 2008 has led to regulatory reforms of the structure of OTC markets (cf. Sidanius and Zikes (2012)). A key benefit of increased central transaction clearing is the sizable reduction of counterparty credit risk (see, e.g., Duffie, Scheicher, and Vuillemey

\footnotetext{
https://www.esma.europa.eu/sites/default/files/library/public_register_for_the_clearing_ obligation_under_emir.pdf
} 
(2015)). By stepping into what was formerly a bilateral trade through novation ("buyer to every seller" and vice versa), CCPs can reduce or reallocate the impact of an institution's distress on its counterparties. CCPs apply stringent membership criteria and require extensive collateralization of positions. Clearing members have to post margins and contribute to the CCP's default funds, which mutualise potential losses above a pre-defined threshold. As CCPs allow for the multilateral netting of exposures, they significantly reduce the size of open exposures and thereby also members' overall collateral and liquidity requirements. Multilateral netting can also reduce the size and complexity of the overall network of exposures. Overall, CCPs face a unique risk profile oriented toward tail risk. Given their important role in the financial system, the US FSOC designated three CCPs as systemically important. The regulatory requirements for the use of CCPs together with comprehensive margining in the bilateral segment have had a substantial effect on counterparty credit risk. In particular, the use of prudent margining has materially reduced the risk of contagion in the OTC derivatives market. As discussed in detail in Financial Stability Board (2017), OTC derivatives markets have become more resilient overall. The leverage ratio complements the riskbased capital requirements by providing a safeguard against unsustainable levels of leverage and by mitigating gaming and model risk across both internal models and standardised risk measurement approaches. By design, the leverage ratio does not differentiate risk across different asset classes. As regards the derivatives exposure calculation , the revised EU regulatory framework CRR 2 / CRD5 packag $\mathrm{f}^{7}$ is coming into force at the time of writing, with a transitory period of 2 years for the roll-out. The leverage ratio is calculated as Exposure Value (adjusted size of balance sheet) relative to Own Funds where derivatives exposures are obtained via the Standardised Approach for Counterparty Credit Risk. SA-CCR uses the weighted sum of Replacement cost (including an alpha factor of 1.4) and Potential Future Exposure of the derivatives trades. Both variables are calculated at the level of the netting set. In addition, the framework recognizes trades in Qualifying CCPs. At the time of writing, the BCBS has also launched a consultation on making the treatment of client exposures less punitive in terms of capital requirement: An adjustment to the initial margin offset of potential future exposure for client cleared derivatives should reduce the capital cost of client trades (BCBS 2019). The previous framework (CRR1), which is relevant for older trades in our sample contained the Original Exposure Method where exposure value made use of a notional

\footnotetext{
${ }^{7}$ See also http://europa.eu/rapid/press-release ${ }_{I} P-18-6659_{e}$ n.htm
} 
adjusted by a factor related to the original maturity: Starting from 0.5 percent for below 1 year, and then 1 percent for each additional year of maturity. This setup implies that transactions with for example $\mathrm{T}=10$ years (a common transaction as we will show) are facing a considerable capital requirement when compared with e.g. FRAs or overnight IRS (based e.g. on EONIA), which is exacerbated by the very high notionals of many major banks' exposures.

\section{Research Issues and Empirical Hypotheses}

In our empirical analysis, we do not build on a single unifying theoretical framework. Instead, we base our hypotheses on theoretical and empirical research on OTC markets more broadly.

These hypotheses, therefore, should be seen as broadly guiding our empirical analysis and allowing us to perform a number of descriptive tests that shed light on trading activity in the IRS market. Hence, the aim of this paper is to deliver a set of descriptive results in order to provide a foundation for future theoretical and empirical work on IRS markets.

Hypothesis 1: In the IRS market, trading is focused on standardised products.

Our first hypothesis is designed to analyse the composition of transactions in the IRS market. In contrast to exchange-traded markets, OTC transactions are executed bilaterally, which leads to decentralisation of trading. An investor who wants to, for example, sell an instrument has to first start a (costly) search for a buyer (Duffie et al. (2005)). The search friction is accompanied by other market frictions. Two additional frictions are (1) lack of transparency about actual transaction prices (cf. Benos et al. (2016)) and (2) the ongoing impact of dealer balance-sheet costs on their trading activity (cf. Andersen, Duffie, and Song (2018)).

Market participants have developed a number of tools to reduce the costs of some of these frictions. One commonly used approach in a number of market segments is to standardise the definition of key features of frequently used instruments, such as the maturity, transaction size, or coupon. Increased harmonisation of instruments then allows for the evolution of benchmark contracts. This process simplifies the search for a counterparty and therefore allows for faster and cheaper matching of buyers and sellers. This evolution can be observed in the single-name CDS market, where trans- 
actions are typically conducted on a maturity of five years, with standardised coupons and senior unsecured debt as underlying instrument (cf. Oehmke and Zawadowski (2016)). As Benos et al. (2016) and Cenedese et al. (2019) discuss, standardisation is also common for US\$-denominated IRS contracts. We test whether this practice is also the case for euro-denominated IRS trading. Our focus is on maturity as a key variable. We also extend the definition of standardisation in terms of the structure of cash flows, therefore adding the "fixed-floating" variable to the analysis.

Hypothesis 2: Network structure:

2a) The core of the network in the IRS market is constituted not only by dealers but also by other major banks: intermediaries.

2b) Non-banks are typically located in the periphery of the network.

2c) The core of the network is non-specialised whereas the periphery is specialised.

We now move from a transaction to a network perspective. As a mitigant to the costly search friction, a group of dealers has emerged in many OTC market segments. Dealers execute trades with smaller or less-active market participants (e.g., non-banks) and typically try to run largely matched positions because their business model is oriented toward intermediation rather than outright risk retention 8 . Dealers aim not to take proprietary positions, thereby avoiding exposure to market risk. Therefore, a key risk for dealers is counterparty risk, which in a crisis can lead to elevated likelihood of contagion via counterparty credit risk (cf. Glasserman and Young (2015)). As Eisfeldt, Herskovic, Siriwardane, and Rajan (2018) document, in the CDS market, trading takes place via a "core" set of dealers, which trade with all market participants, and a "periphery," which only trades with the firms in the core of the market. Hence, firms located on the periphery of the CDS network do not trade with each other, but only with dealers. Based on this finding, we conjecture that the aggregate network in the IRS market is also characterized by a "core-periphery structure" (where the network is defined by the matrix of aggregated bilateral gross / net exposures).

\footnotetext{
${ }^{8}$ The crucial role of G-16 Dealers in many OTC segments has been documented, for example, for corporate bonds (Di Maggio, Kermani, and Song (2017)), municipal bonds (Li and Schrhoff (2018)) or index CDS; or as in CollinDufresne et al. (2019), the main role of dealers is to match instrument buyers and sellers, partly by using the dealer balance sheet.
} 
In contrast to other OTC derivatives market segments (e.g., CDS), the IRS market is used by a very large number of banks because it offers hedging for a fundamental risk of banking, namely interest rate risk (cf. Hofmann et al., 2018 $8^{9}$. This market characteristic implies the potential for a more complex core structure. In particular, we conjecture that some non-dealer bank participants are also located in the core of the market because the structure of their balance sheet implies the need for a large number of transactions.

To identify these "intermediaries" (i.e., banks that act like dealers but are not in the generally used list: 10 ) from our dataset, we analyse activity across major sub-segments of the IRS market. For this purpose, we first define 27 subsegments of the IRS market by categorising transactions according to their currency (EUR, USD, and others), maturity (5 years, 10 years, and others) or cash-flow structure (fixed-floating, floating-floating, and fixed-fixed). We then count in how many of these 27 subsegments a firm has non-zero notional exposure in our sample period. The realised values of this index give us an indication if a market participant is active across all segments (value equal to 27 implies no specialisation) or only a handful (single-digit value-i.e., high specialisation). This approach allows us to apply a data-driven selection of the firms in the core of the network rather than use lists compiled for other market segments or simply the aggregate volume of trade or the total number of counterparties.

We now move from the core to the periphery of the market. An example of an entity located on the periphery is a pension fund that wants to enter into an IRS to hedge its interest rate risk. For this transaction, it will contact a dealer rather than another pension fund because the likelihood of a match is higher with the former rather than the latter, and pension funds are typically not clearing members in $\mathrm{CCP}{ }^{11}$. Hence, clustered nodes typically define a core of key market makers that are closely linked to a large number of other traders.

In addition to the network location, specialisation is another characteristic of a firm's market activity. Our sample comprises instruments in a range of currencies (EUR and USD, but also emerging-market currencies), maturities (from $\mathrm{O} / \mathrm{N}$ to 30 years), or cash-flow profiles (e.g., plain-

\footnotetext{
${ }^{9}$ The single-name CDS market offers hedging only for a small subset of a bank's credit risk exposures. In particular, activity is concentrated on major G-20 and emerging market sovereigns, G-SIBs, and major industrials. Therefore, for many borrowers in a bank's loan book there is no corresponding direct hedge instrument available in the CDS market

${ }^{10}$ G-16 Dealers: Bank of America Merrill Lynch; Barclays; BNP Paribas; Citigroup; Credit Agricole; Credit Suisse; Deutsche Bank; Goldman Sachs; JP Morgan; Morgan Stanley; Nomura; Societe Generale; UBS (cf FSB 2017);

${ }^{11}$ See exemption from clearing obligation under EMIR implementation for Pension Funds.
} 
vanilla fixed-floating, basis swaps, or cross-currency contracts that swap EUR benchmark rates for USD rates). Specialisation is not only relevant in terms of market pricing, but also because of potential market power in smaller and more concentrated market segments.

Hypothesis 3: In absolute as well as relative terms holders of net notional IRS exposure are located both in the core as well as in the periphery of the network.

Our next hypothesis focuses on the transfer of risk in the IRS market via holdings of net exposure. We again take as a starting point the results on the structure of the CDS market (cf. Battiston et al. (2018)). This is characterized by the existence of long chains of intermediation wherein the underlying risk of a reference entity's default is passed between dealers and other market participants (e.g., hedge funds). This process results in a "flow of credit risk"(i.e., the flow of the underlying reference entity's default risk) along this intermediation chain, which leads to interconnectedness among a large number of counterparties, some of which are non-banks. Empirical analysis for bilateral exposures in the CDS market by Battiston et al. (2018), Bellia et al. (2017), and Getmansky et al. (2016) shows that exposure to fundamental credit risk frequently does not remain with the dealers, but instead "flows" to smaller market participants who may also have correlated CDS portfolios.

As a specific proxy for the IRS market, we measure risk absorption by means of a firm's net / gross ratio as well as net notional exposures. We then analyse the determinants of these measures in a regression approach. Given the stylised facts of the CDS market, we conjecture that some of the entities in the periphery of the IRS network are ultimate "risk absorbers" - that is, they fulfil other institutions' demands for interest rate risk hedging.

Our methodology is focused on the trading and risk transfer within the IRS market. Hence, in contrast to Hoffmann et al. (2017), we focus on who bears the specific risk traded in the IRS market rather than interest rate risk more generally (e.g., including all banks' exposures on interest rate risk such as fixed-rate loans or banks' portfolios). Our net exposure analysis is also motivated by new regulatory requirements for comprehensive margining: Traders both in the CCP as well as the bilateral market face the risk of margin calls when their positions are accumulating mark-to-market losses. Hence, from a risk perspective, our analysis is oriented toward understanding the impact 
of high and increasing market volatility on traders' IRS exposures. In this context, our analysis of the structure of net exposures can shed some light on the impact of margin calls on major traders.

Hypothesis 4: Bank size explains a bank's IRS market activity

We next turn to the drivers of the allocation of banks to the core or the periphery of the network of bilateral exposures. We focus on banks due to the availability of comparable balance-sheet information (i.e., the lack of data for hedge funds or pension funds). We investigate whether size is the main determinant of the location in the core-periphery structure of the network. Our analysis of the role of total assets as a determinant of market activity is broadly motivated by the discussion of a bank's size as a proxy for its role in networks of bilateral exposures and its contagion risk (cf. Glasserman and Young (2015)). We also investigate whether a bank's market activity is largely driven by the size of its balance sheet. Moreover, we also study whether there is any relationship between net exposures and bank size by looking first at net over gross notional ratio and then at the net notional.

Hypothesis 5: The role of Basel III capital and liquidity ratios

5a) A bank's regulatory capital ratio (measured by CET1 / risk-weighted assets) and its liquidity ratio (measured by liquid assets / total assets) are positively related to its gross and net notional. 5b) Banks' leverage ratios (as measured by CET1 / total exposures) are positively related to their IRS market activity.

We aim to check whether better-capitalised bank: ${ }^{12}$ and/or banks with a higher liquidity buffer are more active in IRSs. There could be several reasons why a bank's capital and liquidity ratio might affect its market activity. First, a bank's RWA-based capital position (defined as CET1 relative to risk-weighted assets) is a common determinant of a bank's rating and its counterparty risk in general (for a general discussion, see Acharya, Fleming, Hrung, and Sarkard (2016)). We might expect that market participants prefer to trade with an entity that is well-capitalised and therefore more resilient to market shocks. A similar logic applies to a bank's holding of liquid assets, which

\footnotetext{
${ }^{12}$ See also Siriwardane 2018 .
} 
can be directly used to cover any sudden margin calls from CCPs.

However, mandatory clearing should have reduced the relevance of counterparty risk in the selection of a counterparty. A capital ratio that might be more relevant now is the leverage ratio which is defined as capital relative to total assets (i.e., with equal risk weights of $100 \%$ for all instruments irrespective of their risk). Introduced by Basel III, the leverage ratio requires more capital against derivatives exposures, which have a low level of market risk. It also does not fully recognize position offsets and the availability of risk-mitigating collateral (e.g., in its definition of exposure measure). A number of authors (see, e.g., Haynes, McPhail, and Zhu (2018), for the impact of the Basel III leverage ratio on the competition in the option market and Boyarchenko et al. (2018) for a survey) have recently highlighted that the new regulation may affect the cost and therefore the willingness of banks to trade in OTC markets due to the binding nature of the leverage ratio for a number of major firms. This concern is particularly relevant for high-notional markets such as interest rate derivatives or repos. As some major banks have a comparatively weak capital position (relative to total assets), they are not able to provide as much "balance-sheet space" as before the crisis (for a comprehensive discussion, see Duffie (2018b)). For instance, in the context of derivatives clearing for client business, which is also penalised by the leverage ratio, Acosta-Smith, Ferrara, and Rodriguez-Tous (2018) show that the leverage ratio had a "dis-incentivising" effect on client clearing, with a notable reduction in UK banks' willingness to take on new clients. We test this hypothesis in the euro area IRS market by investigating how a bank's market activity is related to its leverage ratio, with particular emphasis on those banks that are in the lower part of the capital distribution. We also investigate how the Basel III capital and liquidity ratios affect net exposures both in terms of net over gross notional ratio and absolute net exposure. In this case, we expect that risk-weighted capital and liquidity ratios are more relevant when risk mitigation across positions is recognized. 


\section{Our Sample and Descriptive Statistics}

\subsection{Derivatives dataset: Transaction-level perspective}

Our dataset builds on regulatory reporting under the EMIR. EMIR requires EU entities to report their derivatives transactions to trade repositories (TRs) authorised by the European Securities Markets Authority (Abad et al. (2016) describe the reporting and associated problems). Hence, all EU-located legal persons (counterparties) entering into a derivative contract must report the details of that contract to a TR.

We obtain transaction-level derivatives data from the main TRs, which in turn have access to the transaction data following the EMIR regulation.

As of March 2018, the following TRs have been authorised by ESMA 13 :

- Bloomberg Trade Repository Limited

- CME Trade Repository Ltd.

- DTCC Derivatives Repository Plc

- ICE Trade Vault Europe Ltd.

- KDPW

- NEX Abide Trade Repository AB

- Regis-TR S.A.

- UnaVista Limited

We use a snapshot of the stock of all open IRS transactions on March 30, 2018, for traders domiciled in the euro area on one side of the transaction. For that date, the EMIR dataset on euro area OTC interest rate derivatives contains 4,042,960 trades.

As the transaction data in TRs include many data errors and also double reporting due to the structure of EMIR reporting, the TR data are not readily usable for research purposes, and hence we perform an extensive cleaning procedure (summarized in Table 1). In particular, we follow the approach of Abad et al. (2016). Our filters are defined as follows:

- Remove transactions with missing data on key variables (missing notional, missing counterparties' IDs)

\footnotetext{
${ }^{13}$ https://www .esma.europa.eu/supervision/trade-repositories/list-registered-trade-repositories
} 
- Remove transactions with clear misreported data, mainly transactions with an implausible value of notional (i.e., lower than 50k and higher than 10bn), but also transactions with implausible maturitiy dates (i.e. before 2018 and after 2050);

- We narrow the time span of contracts execution from 2000 to March 2018, deleting all transactions before 2000;

- Focus exclusively on IRS (e.g., we drop swaptions).

- Drop intragroup transactions (e.g., trades between two subsidiaries within a banking group); this was performed not only using a specific dummy variable available in the dataset for intragroup, but also using our traders' mapping and groups reconciliation;

- Drop double reporting (same trade reported twice) and other inconsistent observations identified due to the EMIR double-reporting obligation;

Application of all these filters together produces a final dataset of 1,666,489 trades. The restrictions on our sample are largely due to data availability and quality problems of reported trades in the EMIR data collection.

Table 2 reports standard summary statistics for the transaction-level dataset. On a transaction level, the main variables of interest, besides the identity of reporting and reported counterparties, are the key features of the contract (i.e., the gross notional amount of the trade) and the effective execution and maturity dates of the transaction.

In Table 2, we separate summary statistics respectively for the overall market, the cleared subsegment (i.e., cases in which one counterparty is a CCP), and the bilateral subsegment (i.e., cases in which two firms clear directly with each other).

Aggregate gross notional equals EUR 98.3 trillion, which means that the volume of our dataset equals $37 \%$ of the global market volume and $98 \%$ of the Euro area market ${ }^{14}$. In total, $55 \%$ is constituted by cleared transactions and $45 \%$ by non-cleared transactions.

The median gross transaction notional across all transactions equals EUR 19.1 million with 25\% of transactions below EUR 6 million, and $25 \%$ of transactions above EUR 50 million. Hence, we both observe transactions with a size that is more of a retail magnitude as well as some very large trades. The standard deviation is three times the mean of the notional, confirming wide dispersion in size. This indicates that we observe a heterogeneous network structure, which includes trans-

\footnotetext{
${ }^{14}$ Source: BIS.
} 
actions from the largest dealers to much smaller banks, other institutions (e.g., investment funds), and corporates. A comparison between the cleared and the bilateral market segments indicates that the average gross notional of a cleared transaction is twice the average notional of a non-cleared transaction.

It is worth highlighting that in the IRS market, gross notional is not a representative measure of risk exposure because only the difference of the fixed and the floating rate is typically exchanged. Nevertheless, the highly positive correlation of gross notional with trade activity shows that notional provides us with detailed information about market structure, especially considering that the variable measuring market value has many misreported value: 15

For the limited subsample, where both variables are available, the average market value is $1 \%$ of the average gross notional. This combination of high gross notional and the low net market value indicate that IRS exposures are frequently adjusted and that an exposure opened at some date is typically not kept unchanged until the maturity of the IRS contract. This corresponding high level of trade activity is a stylized fact also for other OTC derivatives markets. According to Bank for International Settlements (2017), global notional for all counterparties captured by the BIS data collection is EUR 346,594 billion with a market value of EUR 7,082 billion, which equals around $2 \%$ of notional.

Table 2 shows that $50 \%$ of the open trades as of March 30, 2018, are expiring by 2022. This is confirmed by the distribution of IRS contract maturity, with $25 \%$ of contracts having a maturity lower than five years.

\subsection{Aggregation to firm-level perspective}

Our first approach to the definition of firm-specific characteristics uses a categorization of the 282 counterparties in our sample into six different groups. This group covers $95 \%$ of the total market exposure (see also further below).

1. G-16 Dealers (n=16): Due to their role as "core" intermediaries (cf., e.g., Peltonen, Scheicher, and Vuillemey (2014)), we define the category "Dealers" from the list of the main sixteen derivatives dealers as commonly used by researchers (for an example, see Benos et al. (2013)).

\footnotetext{
${ }^{15}$ Similar to market prices, the reporting of market values are particularly prone to data errors (see also Abad et al. (2016)). We therefore focus on notional measures for most of our analysis.
} 
2. Intermediaries $(n=10)$ : We introduce and define this new category of non-dealer banks because we observed a group of large banks that play a role in the market similar to the dealers, and that together with the dealers constitute the core of the IRS market. We describe the details of our identification process below.

3. Banks supervised by the Single Supervisory Mechanism (SSM) that are non-dealers and nonintermediaries $(n=87)$ : As our dataset consists of derivatives transactions in the euro area, we expect banks domiciled in the euro area (i.e., supervised by the SSM) to be more active in this market than banks from other currency regions. Therefore, we define a separate category.

4. Other banks $(\mathrm{n}=46)$ : Non-dealers and non-intermediaries outside the SSM scope.

5. CCPs: Our sample comprises 11 CCPs domiciled in the EU, US or Asia.

6. Non-banks: All remaining counterparties $(\mathrm{n}=112)$ are predominantly investment funds, insurance companies, pension funds, or non-financials. Given that investment funds or asset managers do not publish harmonized data on their balance sheets, this category is omitted in the analysis where we make use of proxies for a firm's capital or liquidity.

We define a large set of dummy variables to test our hypotheses outlined in the previous section. Our second approach makes use of balance-sheet data. We retrieved bank balance-sheet information as of 31/12/2017 from S\&P Global SNL Financial. We matched these data using legal entity identifiers (LEI), but since each group has different branches with different LEIs, we carefully chose group data and then reconciled all branches and subsidiaries within the respective groups. The balance-sheet data are only available on a comparable basis for banks, as many non-banks (e.g., hedge funds or pension funds) do not publish harmonized balance-sheet data. We also collected information on a bank's size (total assets), risk-weighted assets, liquid assets, and two measures of the capital position (CET1 relative to total exposure or risk-weighted assets).

In terms of summary statistics, we first describe the entities in our sample by means of their balance sheets. As Table 3 shows, the sample is dominated by banks with large balance sheets: the biggest bank in our sample has a balance sheet exceeding EUR 2 trillion. The leverage ratio is higher than $5.5 \%$ for half the banks in our sample. According to the liquidity ratio, liquid assets (using the SNL rather than the regulatory definition) are typically one-third of total assets. We also investigate whether the Basel III capital and liquidity ratios are highly correlated (i.e., they 
always capture the same feature of a bank). Panel B of Table 3 shows that this is not the case. Correlation among total assets, CET1 ratio, leverage ratio, and liquidity ratio is low and ranges between 0.35 to -0.30 .

To illustrate the information available in our dataset, we briefly describe the activities of one dealer on one (randomly chosen) day in 2017. On that day, the dataset recorded 425 trades between the dealer and a variety of counterparties:

- 205 with one major EU CCP;

- 139 with other CCPs such as the US or Japan;

- Rest with US G-SIBs, Asian banks, or fixed-income fund;

The total gross notional of new trades equals EUR 26 billion. Maturities range from 3 months to 30 years. Products range from IRS referring to benchmark Euribor to CPI inflation derivatives and to swaps in Emerging Market currencies. This example further confirms the high level of market activity for major firms. A summary of trading activity from a trader perspective is reported in Table 4. We show the differences between the bilateral and the cleared market from a trader perspective. The total number of counterparties in the cleared market amounts to 174, in line with the number of clearing members for the two major CCPs in the EU. In the bilateral market, the number increases to 55,600 and the distribution of firms' exposure falls from an average exposure of EUR 672 billion in the cleared market to EUR 1.4 billion in the bilateral segment. Here most players have a very concentrated activity level, with $75 \%$ of traders active in only one transaction with one counterparty. One driver is the activity of, for example, a large number of individual investment funds that only make use of a very limited number of transactions to fine-tune their interest rate exposure. The distribution of trade activity at trader level confirms the core-periphery structure of the network: 282 counterparties cover $95 \%$ of the overall market exposure. That is why from now on, we will also focus on these 282 counterparts from a network perspective. In our sample constituted by these 282 major players, we observe 4,070 links, which implies a network density of 5\%. Hence, only a small share of all possible bilateral links actually exists. Indeed, for the vast majority of counterparties, there are no direct bilateral links. This indicates that the aggregate IRS network also exhibits the so-called "small world" properties that have been documented for other financial networks, as well as a scale-free degree distribution (see Peltonen 
et al. (2014) for evidence on a similar structure in the global CDS market).

\section{Results}

In this section we investigate the hypotheses described in Section 2.

\subsection{Hypothesis 1: In the IRS market, trading is focused on standardised prod- ucts.}

We first investigate the concentration on standardised products by exploring the distribution of the trade frequency and volume across cash flow contract structure, maturities, and currencies. Figure 1 plots these distributions. Figure 1 shows that both in terms of number of trades and volume, the fixed-floating contract is the most common; in terms of currency, the euro is the most common; and in terms of maturities, the "typical" (i.e., the most commonly traded) IRS contract in the Euro area market has a maturity of 5 or 10 years.

Floating-floating and fixed-fixed swaps are far less common. We observe roughly 20,000 fixed-fixed contracts (1\%), out of which 13,613 are cross-currency, with $25 \%$ of the cross-currency transactions for the EUR-USD currency pair. This empirical evidence confirms our Hypothesis 1: In the IRS market, trading is focused on standardised products. As regards the execution date of the trades in our sample, half of the transactions have been executed from 2016 to the sample cut-off in March 2018. This concentration in shorter maturities may also be due to back-loading of trades in the TRs and the clearing obligation, which creates incentives for clearing members to also novate their

old trades to the CCP to obtain the netting benefits (cf. Duffie et al. (2015)). The impact of the clearing obligation in defining the cleared versus bilateral market is visible when comparing the two columns in Table 2, Non-cleared contracts are indeed from older vintages: half of them were executed by 2015. Most recent transactions tend to be cleared: 25\% were executed from 2015 to 2017 , and $50 \%$ of them were executed during the last year.

In sum, we find that trading activity is concentrated in standardised IRS transactions and largely cleared in the most recent period (about $81 \%$ ). 


\subsection{Hypothesis 2: Network structure:}

2a) The core of the network in the IRS market is constituted not only by dealers but also by other major banks: intermediaries.

2b) Non-banks are typically located in the periphery of the network.

2c) The core of the network is non-specialised whereas the periphery is specialised.

In Hypothesis 2, we move from the transaction-level view of our dataset to the aggregated (i.e., firm-level) analysis. Here, we apply a network perspective to analyse "who trades with whom."

We show a stylized chart of the network with all major categories of firms in our sample in Figure 2. from the perspective of the ECB-supervised euro area banks. It clearly illustrates the dominant role of CCPs and core firms. As of March 2018, $62 \%$ of the total gross notional of SSM banks was concentrated in global CCPs.

To investigate the concept of dealer and understand who is actually performing a dealer function in the IRS market with similar trading characteristics, although not officially defined as dealers, we calculate an index based on the number of different types of contracts traded by the firms in our sample. We divide the type of contracts into 27 different categories based on currency, maturity, and cash flows exchanged (fixed, floating) ${ }^{16}$. We compute for each trader the number of transactions in each category: we create a dummy equalling 1 if the counterparty traded at least once on that type of contract, and 0 otherwise. We obtain an index with values from 1 to 27, where 1 is a highly specialized counterparty trading only one type of contract (e.g., EUR 10-year Fixed-Floating), whereas a value of 27 indicates that a firm is acting as intermediary by trading all possible types of IRS contracts contained in our sample. Results are displayed in Table 5, where we show that not only dealers but also some major non-dealer banks act as intermediaries, trading all different types of IRS. The index shows that 10 firms, which do not belong to the dealer group, nevertheless are active in all subsegments of the euro area IRS market. Hence, as Table 5 shows,

\footnotetext{
16 The 27 categories are: EUR 5yrs FixFloat, EUR 10yrs FixFloat, EUR other maturities FixFloat, EUR 5yrs FixFix, EUR 10yrs FixFix, EUR other maturities FixFix, EUR 5yrs FloatFloat, EUR 10yrs FloatFloat, EUR other maturities FloatFloat, USD 5yrs FixFloat, USD 10yrs FixFloat, USD other maturities FixFloat, USD 5yrs FixFix, USD 10yrs FixFix, USD other maturities FixFix, USD 5yrs FloatFloat, USD 10yrs FloatFloat, USD other maturities FloatFloat, Other currencies 5yrs FixFloat, Other currencies 10yrs FixFloat, Other currencies Other maturities FixFloat, Other currencies 5yrs FixFix, Other currencies 10yrs FixFix, Other currencies Other maturities FixFix, Other currencies 5yrs FloatFloat, Other currencies 10yrs FloatFloat, and Other currencies Other maturities FloatFloat.
} 
the total group of core firms consists of 16 dealers (4 from the euro area) plus 10 intermediaries (6 from the euro area) plus 11 CCPs (the latter by construction situated in the core of the network due to their high interconnectedness). In the periphery of the network, we find in the category "other banks" 46 firms, then 87 other SSM banks (i.e., smaller banks domiciled in the euro area), 14 insurers / pension funds, and 98 other non-banks (note that we have a cutoff at $95 \%$ equal to $\mathrm{n}=282$ of the total sample to improve the presentation in the tables and charts).

Following this approach and treating non-dealer intermediaries as a separate category situated between the categories of dealers and SSM banks, respectively, we compare in Table 5 other major dimensions of market activity. We are interested in variables that can help us identify new categories of traders playing important roles in the market. From the magnitude of the average exposure for dealers, intermediaries, and SSM banks, we can see how dealers and intermediaries report average gross exposure which is far higher than in other categories. This difference is particularly striking for dealers: for dealers we observe a total gross notional of EUR 80.3 trillion. For intermediaries in the euro area, the amount is 14 trillion, and for non-euro area intermediaries, the amount is 1.2 trillion. For other SSM banks that are clearing members, the amount is 11.1 trillion, and for SSM banks that are non-clearing members, the amount is 7 trillion. In terms of notional magnitude, nonbanks are far less active. The ranking according to gross notional is also reflected in the measures of net notional. Our index, therefore, allows us to interpret the observed volume of trading and number of counterparties, both indicators previously used to identify institutions that are at the core or in the periphery of a network.

In aggregate, we report an open position for the sector of CCPs because our sample coverage is not global, but only captures the activities of euro area institutions (on at least one side of the transaction). Hence, for a transaction between a SSM bank and a US dealer, we observe the trade between SSM bank and CCP, but we miss the trade between CCP and the US dealer. This distinction explains that for CCPs, we report a net open position (around EUR 8 trillion).

Figure 3 illustrates the network structure of the euro IRS market by means of a plot of the matrix of bilateral exposures $G$. In this matrix, element $G\{i ; j\}$ equals 1 if $i$ and $j$ have a non-zero bilateral exposure. Counterparties are ordered by their total exposure, highest to lowest, starting with the largest dealers located in the bottom-left corner. Each dot in the chart indicates the presence of a link between counterparties i and j. As Eisfeldt et al. (2018) argue, a core-periphery network is 
characterized by a matrix $\mathrm{G}$, with ones along the diagonal, a core of dealers each represented by a column and row of ones, and zeros elsewhere. The chart with sample size $n=1000$ indicates a high level of interconnectedness among the dealers and intermediaries ("Core" in the bottom-left corner) and weaker interconnectedness among other firms who trade only with the core, as confirmed by the absence of links in the top-right corner. Therefore, many counterparties (e.g., smaller banks or non-banks) are connected in the network through a few key dealers with whom they trade material volume and who are also active in many transactions.

The high level of interconnectedness and the key role of euro-domiciled intermediaries are further supported by Figure 4. We use a scatter plot with aggregation to show for SSM banks the number of counterparties and the gross notional on the horizontal versus vertical axes. Due to data confidentiality, we cannot show information for individual firms, hence we define three groups in the scatter plot. The chart clearly indicates that the intermediary category plays an important role in the bilateral trading. We now extend the description of the bivariate activity of IRS traders. Looking at the overall sample, Figure 5 illustrates the developments for "who trades with whom" before and after the clearing obligation started in June 2016. We observe that market activity became concentrated around dealers and CCPs after the start of the clearing obligation. Almost all categories shrink their exposures with respect to the dealers, with the consequent concentration of most market exposure in the hands of a few traders (dealers and CCPs). We also observe that - in part mechanically - CCPs' contribution is steadily increasing. Also due to the clearing obligation, activity with CCPs has increased from $66 \%$ in the pre-clearing obligation period (from 2000 to 2016 included, considering that the obligation came into force for most traders in 2016) to $81 \%$ in the post-clearing obligation period (2017 and 2018, with data up to March only). The dealer-CCP segment has - in relative terms - witnessed the biggest increase with respect to the overall market, while in all other segments both bilateral and cleared activity is narrower than the dealer-CCP share in the market. Therefore the IRS market's structural dependence dealers is still evident, despite CCPs' increased activity. In parallel, dealers also play a pivotal role as major clearing members (see, e.g., Lin and Surthi (2013) for an illustration of the key role of G-SIBs in major global CCPs). The mutualisation of default resources in CCPs implies that the dealer counterparty credit risk is a strong determinant of the CCPs resilience, as the CCPs' own financial resources are typically modest. Thus, the soundness of dealers' solvency and liquidity positions continues to be 
essential for safeguarding the stability of the OTC market overall.

In sum, our analysis confirms that the IRS network is not just concentrated around dealers, but that intermediaries do indeed play an important role as well.

We complete the analysis of Hypothesis 2 (a, b, and c) with a regression analysis to test whether the activity of the financial institutions grouped in a subset of 10 categories are indeed statistically different. We start by investigating market activity on a cross-sectional perspective using an OLS estimation model. The regression specification is

$$
\text { Trade Activity } \text { A }_{k}=\alpha+\beta_{j} * X+\varepsilon_{k}
$$

Where the dependent variable Trade Activity $_{k}$, is equal to the total gross notional (natural log value) of firm $\mathrm{k}, \beta_{j}$ is the dummy for category $\mathrm{j}$ of the trader $\mathrm{k}$, and $\mathrm{X}$ is a dummy interaction variable to separate dealers and intermediaries domiciled in the euro area vs non-euro area dealers and intermediaries, or other banks and non-banks that are clearing members versus non-clearing members. Total exposure, expressed as the log value of the gross notional, is computed by aggregating the gross notional of all open positions for the fully identified counterparties (271 traders, excluding the CCPs) in our sample.

Predictor variables in our first specification are dummy variables for each of the categories that we distinguish in the market. The dummy is 1 if the counterparty belongs to that category and 0 otherwise. To understand market structure more precisely, we interact the categories with additional dummy variables equal to 1 if the Dealer or Intermediary belongs to the euro area, and a dummy variable equal to 1 if the SSM banks, other banks, and non-banks are clearing members. Our reference category is "SSM banks that are not clearing members." We focus on dealers and intermediaries in the euro area because this group is particularly significant if we consider the EMIR reporting obligation: it applies to entities established in the EU who enter into, modify, or terminate certain derivatives transactions. This means that for an EU dealer, the aggregate gross exposure we can obtain from EMIR data represents the full picture of the dealer in the IRS market, whereas -as mentioned earlier- for US dealers, we only observe their activity in the Euro IRS market with EU counterparties, therefore generating a partial sample of a US dealer's trading activity in IRSs. Finally, investigating the network structure by means of OLS estimation allows us to test 
the statistical significance of this new category that we identify and define as Intermediaries.

Table 6 shows the results of our baseline regression of gross notional exposure on the different categories of market traders. Column 1 of Table 6 shows that dealers as well as SSM clearing members have a larger gross notional amount than SSM non-clearing members. Moreover, clearing members in general have a larger gross notional amount, so they are more active than firms that are not clearing members. This analysis confirms the results from the summary statistics and shows that the relevance of dealers and intermediaries is not driven by a single institution, but statistically, the single dealers and clearing members indeed represent a level of activity that is far larger than the others' activities.

Moving from column 1 to column 2 of Table 6, we now distinguish between dealers and intermediaries, as the latter seem to have an important role as well in the IRS markets. The regression confirms that this group of major non-dealer banks has a significant market activity. The coefficients indicate that the intermediaries have a level of activity similar to dealers - non-EMU in the euro area IRS market. Indeed, the separate identification of this category is accompanied by an increase in the R-squared of the regression. Since the coefficient for intermediaries-euro area is lower than for dealers-euro area and higher than SSM banks-clearing members, we use the F-Test to test (1) that the trade activity of euro area dealers = euro area intermediaries; and (2) that the trade activity of euro area intermediaries = SSM banks clearing members ${ }^{17}$. The results of the F-Test indicate that (1) we can reject the equality hypothesis (i.e., euro area dealers $\neq$ euro area intermediaries); and (2) we can also reject the equality hypothesis for intermediaries and SSM banks. To correctly interpret the results and the magnitude of the single traders, we need to keep in mind that the category "Dealers - Euro area" contains 4 banks, "Intermediaries - Euro area" contains 6 banks, and "SSM banks - clearing members" contains 28 banks. These findings provide further support to our hypothesis that the new category of major non-dealer banks acting as intermediaries is indeed a combination of the profiles of G-16 Dealers and SSM banks - clearing members, constituting itself as a second-level-core, which is located between the "traditional" core represented by the G-16 Dealers and the periphery of smaller banks and non-banks.

In sum, the regression analysis therefore confirms Hypothesis $2 \mathrm{a}$ and $2 \mathrm{~b}$ (i.e., that dealers and

\footnotetext{
${ }^{17}$ We do not distinguish clearing members from non-clearing members in the dealer and intermediary categories because the firms in these two categories are all clearing members.
} 
intermediaries are at the core of the network and that non-banks are largely at the periphery of the network).

With the same methodology, we now test Hypothesis 2c (i.e., whether banks are non-specialized, whereas non-banks are specialised). As discussed earlier in the context of Figure 1, trading in the IRS market is focused on standardised products. As a next step in the structural analysis, we move toward an investigation of trader specialization. We focus on two key dimensions of the concentration of a firm's trading activity: (i) maturities and (ii) currencies.

In this section, we use the regression approach introduced above to investigate specialization at firm level. In particular, we study whether some groups of firms focus on only certain types of IRSs. Given that in our sample, the complete picture of trade activity is only available for EMU financial institutions, we concentrate on the subsample of the 148 banks. The dependent variable (gross notional) is divided into 12 different types of contracts based on the cash-flow structure (fixed/floating, floating/floating, fixed-fixed) and four maturities buckets (1-3yrs, 4-6yrs, 9-11yrs, and others). Since our database focuses on firms from the euro area, by construction there is a concentration on EUR-denominated contracts, and therefore we perform three different regressions for three types of currencies: (i) EUR, (ii) USD, and (iii) others. In particular, we run the following regression 18

$$
\text { Trade Activity } \text { k,y,i }=\alpha+\beta_{j}+M_{y}+\beta_{j} * M_{y}+\varepsilon_{k, y, i}
$$

Where:

TradeActivity $_{k, y, i}=$ Total gross notional of trader $\mathrm{k}$ on a specific contract maturity bucket $\mathrm{y}$ (1-3 yrs, 4-6yrs, 9-11yrs and others) and cash flow structure i (fixed/floating, floating/floating, fixedfixed)

$\beta_{j}=$ Dummy for category $\mathrm{j}$ of traders

$M_{y}=$ Dummy for the maturity buckets y

The estimates for the regression coefficients are reported in Table 7. Columns 1, 2, and 3 of

\footnotetext{
${ }^{18}$ In order to avoid any bias in this regression due to structural features in the dataset, we consider only the period from April 2017 to March 2018 (specifically to avoid overestimation on contracts with longer maturities), and we eliminate contracts expiring in the next few months. The reference group in this specification is constituted by SSM banks (i.e., smaller banks domiciled in the euro area that are neither dealers nor intermediaries).
} 
Table 7 show the results for the three different currency buckets in which we divided the total gross notional, respectively: gross exposure for contracts in EUR, in USD and in all other currencies. Table 7 shows that overall, there is a different specialization in maturities among the three currencies. For EUR-denominated IRSs, there is a concentration on five years; for USD IRSs, the concentration is more on the one-to-three years and the five years. For the other currencies, there is no specific maturity that dominates.

Dealers report higher exposures on standard 10-year-maturity contracts in EUR and USD contracts, while for the other contracts, there is no particular specialisation. Intermediaries do not seem to be specialised in any maturity, which is consistent with their function of intermediation

in the market. The category "other banks" is more focused on currencies other than EUR, with a predominance of 10 year-contracts traded in other currencies and very short-term contracts traded in USD.

For robustness, we perform a similar regression by grouping all the contracts in the different maturity buckets and investigate whether dealers show a specialisation on currencies. The analysis shows that dealers are not significantly specialised in a particular currency, and that intermediaries are more specialised in the EUR currency (results are provided in the on line appendix).

\subsection{Hypothesis 3: In absolute as well as relative terms holders of net IRS exposure are located both in the core as well as in the periphery of the network.}

The granular nature of our data set allows us to study in detail the structure of net exposures. In particular, we now investigate the flow of interest rate risk as it is captured by the cash flow structure and risk-return tradeoff of plain-vanilla IRS. We are aware that a net IRS exposure might indicate a proprietary position, a hedging position of other balance-sheet exposures, or a client exposure. As Hoffmann et al. (2017) show, the composition of a bank's mortgage book, in particular the share of fixed-rate versus floating-rate exposures, is a key factor for the structure of a bank's interest rate risk. They also find that euro area banks' derivative positions reduce their balance-sheet IR risk exposure by around $25 \%$ on average. For our global sample of banks, there are no consistent and reliable publicly available measures of interest rate risk. Therefore, we cannot pursue the analysis 
of the disaggregated firm-specific motivation for IRS trading further. In particular, the lack of data precludes us from disentangling the hedging of balance-sheet positions, proprietary trading, and position taking for third parties. Our methodology, which is closely determined by the limitations of the dataset, does not allow us to distinguish these motives for IRS trading in detail. Nevertheless, our analysis is per se important because it allows us to investigate who is taking either the fixed or floating interest rate risk in this market and is therefore potentially affected by margin calls in case of sizable shocks on the level or volatility of interest rates.

Given their vital role as market makers, dealers typically run matched positions. In essence, their business model is oriented toward intermediation rather than outright retention of interest rate risk. Dealers (and intermediaries) are therefore both buyers and sellers and generate a complex network of exposures. This interconnected series of risk transfers among market players creates a mechanism that the literature discusses as a "flow of risk" (cf. Battiston et al. (2018)).

In the previous sections, we have already reported the summary statistics for the net exposure across categories, both in terms of distribution across traders (Table 4) and aggregate values (Table 5). We now implement the concept of risk absorption to study the flow of risk in the IRS market. For this purpose, we compute the ratio of net over gross notional. Table 5 shows that the sum of the net exposures is positive and equal to EUR 12 trillion for dealers and negative for all the other categories. The second-largest net exposure in absolute terms is represented by CCPs and is equal to 7.9 trillion, indicating that there is a significant flow of risk that is matched by noneuro financial institutions. The third-largest category consists of the intermediaries from the euro area and the fourth is non-banks with, respectively, EUR 1.3 trillion and 1 trillion. However, the ranking is quite different if we consider the net over gross notional ratio, where, among the euro area financial institutions, those with the largest ratio are non-banks and other banks that are non-clearing members, indicating that their positions are more directional. A detailed description of the distribution of the net over gross ratio is reported in Figure 6 for all 282 firms included in the analysis. Figure 6 shows that the institutions with the largest net/gross ratio are the other banks and non-banks showing both a positive and a negative large net over gross ratio, and those with a net over gross ratio close to zero are dealers, intermediaries, CCPs, and insurance companies. Hence, the large net notional volumes that we observe for dealers are to a large part due to their large gross notional exposures. In this context, we also highlight a structural difference with IRSs 
compared to other OTC derivatives such as CDS. As Bellia et al. (2017) illustrate, in the CDS market, dealer absolute net exposure is far lower than almost all other market participants, even if their gross notional is several times larger than all other market participants.

We use the regression setup introduced above to test the nature of the flow of risk. In particular, we try to detect which categories function as risk absorbers in the euro area IRS market. For this purpose, we focus on two measures:

- The ratio of net divided by gross notional which indicates how much each trader is exposed on one side (fixed / floating) with respect to its overall exposure;

- The absolute value of the net notional.

By using these two dependent variables, respectively reported in column 1 and 2 of Table 8, we can study the risk absorption, both at trader level and also at the level of the market overall. The specification of the baseline regression on risk absorption is

$$
\text { Net Exposure } \text { Ex }=\alpha+\beta_{j} * X+\varepsilon_{k}
$$

Where Net Exposure ${ }_{k}$ is, for the first regression, the ratio computed as the net notional over the gross notional for every trader $\mathrm{k}$, in absolute value; and for the second regression, the aggregate net notional in absolute value; $\beta_{j}$ are dummies for the different categories of traders in which the market is divided and $\mathrm{X}$ is a dummy interaction variable that separates dealers and intermediaries domiciled in the euro versus non-euro area, or other banks and non-banks that are clearing members as opposed to non-clearing members. In contrast to the previous setup, we now split the non-bank category, separating insurance companies and pension funds from the other non-banks. The motivation for this approach is that we expect these two subcategories to have different risk profiles due to the different natures of their businesses.

The results are reported in Table 8 . The first column of Table 8 shows that the net/gross notional ratio for dealers EMU is in the lower part of the range and roughly similar to positions for dealers outside the euro area and intermediaries from the euro area. We find similar results for SSM banks that are clearing members as well as for insurance companies and pension funds. This means that if we normalize by trading activity, traders with the larger net/gross notional ratio are SSM non-clearing members, and other banks. The coefficient for dealers EMU is now less significant 
and lower (i.e., it is less negative compared with the other categories, suggesting a higher net over gross exposure). Moving from the trader perspective to a broader perspective with the regressions dependent variable expressed as the net notional in absolute value in column 2 of table 8 , we observe that the dealers and intermediaries remain the most significant traders, bearing the bulk of the IRS market exposure in absolute value.

In sum, these results allow us to accept our Hypothesis 3. We confirm that net notional exposures are located both in the periphery, where smaller entities are more exposed, but at the same time, the mass of market exposure remains in the core where dealers (also due to their larger gross notional) are more exposed than other major firms.

\subsection{Hypothesis 4: Bank size explains bank's market activity.}

The use of IRSs is also closely linked to the size and composition of a bank's balance sheet. In particular, large banks and those who hold a large fraction of their assets in loans, bonds, or deposits for which hedging of interest rate risk is necessary from a business-model perspective, might be very active in the IRS market. In this section, we add bank size, expressed as total assets (in $\log$ value), to our set of explanatory variables and investigate to what degree market activity is explained by differences in size.

We therefore add the bank size to the regression equation (1). The baseline regression is now

$$
Y_{k}=\alpha+\beta_{j} * X+B A_{k}+\varepsilon_{k}
$$

Where $Y_{k}$ is the dependent variable considered in equations 1 and 4 (i.e., log of gross notional, absolute net over gross ratio exposure, $\log$ of absolute value of the net notional exposure). $B A_{k}$ is the $\log$ of total assets of bank $\mathrm{k}$ as of the end of 2017. For this specification, the number of observations is smaller than in the previous regression analysis because balance-sheet data were not available for all banks, and in particular, there are no comparable data for non-banks (e.g., hedge funds). Results are reported in Table 9 .

The first column of Table 9 shows that banks with larger balance sheets also have a higher exposure to IRSs. The coefficient is positive and significant at the $1 \%$ level. Indeed, after introducing the log 
of total assets in our regression, we can see how only three categories keep their significance with respect to the reference group: Dealers - Euro area, Intermediaries - Euro area, and SSM banks - clearing members. The other categories have now become insignificant and their differences in trading activity are largely driven by their differences in size. Column 2 of Table 9 illustrates the role of bank size on the net over gross exposure ratio. As expected, log of total assets is not any more significant, and results are similar to those already presented above. In column 3, we also investigate whether the absolute differences in net exposure are driven by bank size. The regression results show that the coefficient for log of total assets is significant and positive, and that only the coefficient of dealers and intermediaries remains significant, indicating that the net exposure for the other institutions is largely driven by bank size. Finally, as a robustness check, we divide the net exposure by bank size, confirming that the only difference in this ratio refers to dealers and intermediaries.

In sum,we can accept Hypothesis 4 on the role of banks' size data explaining the structure of market activity. Nevertheless, bank size cannot explain the important role of dealers and intermediaries in the IRS market.

\subsection{Hypothesis 5: Basel III capital and liquidity ratios:}

5a) Bank capital (measured by CET1/risk-weighted assets) and liquidity (measured by liquid assets / total assets) ratios are positively related to a bank's gross and net notional.

5b) Banks' leverage ratios (as measured by CET1 / total exposures) are positively related to their IRS market activity.

In the analysis so far, we have documented that dealers and intermediaries play an important role in the IRS market in terms of trading activity and net exposure and that their role is not completely explained by the size of their balance sheets. We now investigate the role of Basel III capital and liquidity ratios in influencing trading activity.

We extend the previous specification by adding three explanatory variables derived from bank balance-sheet data, namely liquidity ratio (SNL variable "Liquid Assets" divided by total assets), CET1 ratio, computed as CET1 capital over risk-weighted assets, and the leverage ratio (fully 
loaded CET1 and additional tier 1 capital divided by total leverage exposure). We then interact the leverage ratio and total assets variables to investigate their combined effect. Our fifth specification is:

$$
\text { Trade Activity }_{k}=\alpha+\beta_{j}+B A_{k}+R W C_{k}+L R_{k}+L_{k}+L_{k} * B A_{k}+\varepsilon_{k}
$$

Where the LHS remains the same as in the previous specification, $R W C_{k}$ is the risk-weighted capital ratio, LR the liquidity ratio, and L the leverage ratio for bank $\mathrm{k}$ as of the end of 2017 . and $L_{k} * B A_{k}$ is the variable generated by interacting the leverage ratios with banks' total assets.

Table 10 shows the results of this set of regressions. Comparing the liquidity ratio and leverage ratio, only the second one is significant for the gross exposure prediction. The negative sign suggests that banks' leverage ratios (as measured by CET1 / total exposures) are negatively related to their IRS market activity. This is an additional effect caused by including in the denominator a more coarse measure of the derivatives exposure. Therefore, banks that are more active in trading derivatives (especially derivatives with large notionals, such as IRSs) have lower leverage ratios (as confirmed by Table 5). To better understand the impact of banks' leverage ratio on IRS trading activity, we interact the leverage ratio with bank size. This interaction coherently suggests that banks with lower leverage (i.e., higher capital to total assets) are more active in IRS.

To further ivestigate our hypothesis on the role of capital and liquidity, we use an F-test to check the equality hypothesis of "euro area dealers versus euro area intermediaries" and the equality hypothesis of "euro area intermediaries versus SSM banks." This time, we cannot reject the equality hypothesis for dealers and intermediaries, but we reject the equality hypothesis for intermediaries and SSM banks. The result suggests that IRS market activity is not significantly related to a bank's liquidity, whereas capital indeed plays a significant role. While, as tested before, in terms of trading activity, intermediaries represent a hybrid category between SSM banks and dealers, when including balance-sheet variables, we find that their activity is more similar to dealers than to SSM banks.

In sum, the regressions in this section confirm the findings by Acosta-Smith et al. (2018) or Haynes et al. (2018) on the leverage ratio as a factor which may restrict bank participation in the OTC derivatives markets. 


\section{Robustness analysis}

Our analysis is based on the transactions still active on March 31st 2018. To investigate whether the results are largely affected by the day we selected we re-estimate the baseline regression with the sample for September, 30th 2017 rather than March 2018. Table 11 shows the results. The analysis shows that the categorization of banks and non-banks into the different groups used in our analysis holds even when considering a different point in time (i.e., from 1970 to September 2017, in this check).

Second, we re-estimate the baseline regression of the distribution of risk absorption with fixedfloating swaps only, thereby dropping the fixed-fixed and floating-floating contracts or contracts that cannot be clearly defined. See Figure 1 for the concentration of fixed-floating contracts in our sample. Table 12 shows that, the results are confirmed.

Finally, we analyse the impact of dropping noneuro area intermediaries. Table 13 shows the results of our first baseline regression on trade activity (LHS: log of gross notional) excluding from the sample the intermediaries that do not belong to the euro area. The results are confirmed.

\section{Conclusions}

This paper uses a number of perspectives to investigate the anatomy of the euro area IRS market by using notional measures of transaction activity. We move from the transaction level to the level of aggregate exposures. Our approach provides new evidence to regulators and policy makers regarding the structure and activity in the IRS market along two dimensions: (1) risk absorption and (2) the impact of regulatory reforms such as the clearing obligation and the role of Basel III capital and liquidity ratios in influencing trade activity.

Overall, we show that on one side, the structure of the market in terms of trading activity is not just concentrated on a few global dealers. We highlight the relevance of the role of other institutions (intermediaries) that provide a significant contribution to trading activity. As regards net expo-

sures, we document that our measure of risk absorption is not just concentrated at the periphery of the network, but also at the core, and this differentiates the IRS market from other OTC deriva- 
tives markets like CDS. Moreover, we show that bank size is not the only variable able to explain differences in trading activity, but Basel III capital and liquidity ratios play a significant role in a market where counterparty credit risk now has been dramatically reduced due to the mandatory clearing obligation. In terms of the Basel III capital and liquidity ratios, the leverage ratio has an important role in explaining trading activity. We find that firms having a larger capital over total exposure ratio have lower trading activity. This is due to a peculiarity of the small and medium banks whose leverage ratios often exceed those of larger banks. In contrast, for large banks, different leverage ratio levels influence their trading activity. We find that firms having a larger capital over total exposure ratio have lower trading activity. Our analysis confirms the claims of some market observers (cf. Haynes et al. (2018)): The leverage ratio imposed by Basel III may provide a constraint to the trading activity in the IRS market even if it has no direct material effect on the net over gross ratio. The other Basel III ratios such as risk-weighted capital requirement or liquidity ratios have no significant effect on explaining trading activities. Regarding net exposure, the only exception is the risk-weighted capital requirement. Here, a larger ratio is linked to a larger net exposure on the IRS market. 


\section{References}

Abad, J., I. Aldasoro, C. Aymanns, M. D’Errico, L. Fache Rousová, P. Hoffman, S. Langfield, M. Neychev, and T. Roukny. 2016. Shedding light on dark markets: First insights from the new EU-wide OTC derivatives dataset. ESRB Occasional Paper, No. 11.

Abbassi, P., and F. Bruning. 2018. The Pricing of FX Forward Contracts: Micro Evidence from Banks Dollar Hedging. Federal Reserve Bank of Boston Working Paper, No. 18-6.

Acharya, V., M. J. Fleming, W. B. Hrung, and A. Sarkard. 2016. Dealer financial conditions and lender-of-last-resort facilities. Journal of Financial Economics, pp. 1-27.

Acosta-Smith, J., G. Ferrara, and F. Rodriguez-Tous. 2018. The impact of the leverage ratio on client clearing. Bank of England Staff Working Paper, No. 735.

Adrian, T., E. Etula, and T. Muir. 2014. Financial Intermediaries and the Cross-Section of Asset Returns. Journal of Finance.

Andersen, L., D. Duffie, and Y. Song. 2018. Funding value adjustments. Journal of Finance .

Arora, N., P. Gandhi, and F. A. Longstaff. 2012. Counterparty credit risk and the credit default swap market. Journal of Financial Economics 103:280-293.

Bank for International Settlements. 2017. Semiannual OTC derivatives statistics at end-2016.

Battiston, S., M. D'Errico, M. Scheicher, and T. Peltonen. 2018. How does risk flow in the credit default swap market. Journal of Financial Stability 35:53-74.

Bellia, M., R. Panzica, L. Pelizzon, and T. Peltonen. 2017. The demand for central clearing: to clear or not to clear, that is the question. ESRB Working Paper, No. 62.

Benos, E., R. Payne, and M. Vasios. 2016. Centralized trading, transparency and interest rate swap market liquidity: Evidence from the implementation of the Dodd-Frank Act. Working Paper.

Boyarchenko, N., T. M. Eisenbach, P. Gupta, O. Shachar, and P. Van Tasse. 2018. BankIntermediated Arbitrage. Federal Reserve Bank of New York Staff Reports, No. 858. 
Brunnermeier, M., L. Clerc, and M. Scheicher. 2013. Assessing contagion risks in the CDS market. Banque de France, Financial Stability Review, 7:123-134.

Cenedese, G., P. Della Corte, and T. Wang. 2017. Currency Mispricing and Dealer Balance Sheets. Working Paper.

Cenedese, G., A. Ranaldo, and M. Vasios. 2019. OTC Premia. Journal of Financial Economics Forthcoming.

Cielinska, O., J. Andreas, U. Shreyas, J. Tanner, and M. Vasios. 2017. Gauging market dynamics using trade repository data: the case of the Swiss franc de-pegging. Bank of England Financial Stability Paper, No. 41.

Collin-Dufresne, P., B. Junge, and A. B. Trolle. 2019. Market Structure and Transaction Costs of Index CDSs. Forthcoming.

Di Maggio, M., A. Kermani, and Z. Song. 2017. The value of trading relations in turbulent times. Journal of Financial Economics 124:266-284.

Du, W., S. Gadgil, M. Brody, and C. Vega. 2017. Counterparty Risk and Counterparty Choice in the Credit Default Swap Market. Working Paper.

Du, W., A. Tepper, and A. Verdelhan. 2018. Deviations from covered interest rate parity. The Journal of Finance, 73:915-957.

Duffie, D. 2012. Dark Markets: Asset Pricing and Information Transmission in Over-the-Counter Markets. Princeton University Press .

Duffie, D. 2018a. Over-the-Counter Market Efficiency. Nobel Symposium on Money and Banking, Stockholm.

Duffie, D. 2018b. Post-Crisis Bank Regulations and Financial Market Liquidity. Baffi Lecture .

Duffie, D., N. Garleanu, and L. H. Pedersen. 2005. Over the Counter Markets. Econometrica, $73: 1815-1847$.

Duffie, D., N. Garleanu, and L. H. Pedersen. 2007. Valuation in Over-the-Counter Markets. Review of Financial Studies, 20:1865-1900. 
Duffie, D., M. Scheicher, and G. Vuillemey. 2015. Central clearing and collateral demand. Journal of Financial Economics, 116:237-256.

Eisfeldt, A. L., B. Herskovic, E. Siriwardane, and S. Rajan. 2018. OTC Intermediaries. Working Paper.

Fiedor, P., S. Lapschies, and L. Orszaghova. 2017. Networks of counterparties in the centrally cleared EU-wide interest rate derivatives market. ESRB Working Paper, No. 54.

Financial Stability Board. 2017. Review of OTC derivatives market reforms: Effectiveness and broader effects of the reforms. Available at www.fsb.org.

Fleckenstein, M., and F. A. Longstaff. 2018. Shadow funding costs: Measuring the cost of balance sheet constraints. NBER Working Paper Series, No. 24224.

Getmansky, M., G. Girardi, and C. Lewis. 2016. Interconnectedness in the CDS market. Financial Analysts Journal 72:62-82.

Glasserman, P., and H. P. Young. 2015. How likely is contagion in financial networks? Journal of Banking ES Finance 50:383-399.

Glasserman, P., and H. P. Young. 2016. Contagion in financial networks. Journal of Economic Literature 54:779-831.

Hau, H., S. Langfield, and G. Vuillemey. 2017. Discriminatory pricing of over-the-counter derivatives. ESRB Working paper, No. 61.

Haynes, R., L. McPhail, and H. Zhu. 2018. Assessing the impact of the Basel III leverage ratio on the competitive Landscape of US Derivatives Markets: Evidence from Options. CFTF Policy Brief .

He, Z., B. Kelly, and A. Manela. 2016. Intermediary asset pricing: New evidence from many asset classes. Journal of Financial Economics, 126:1-35.

Hoffmann, P., S. Langfield, F. Pierobon, and G. Vuillemey. 2017. Who bears interest rate risk? ECB Working Paper, No. 2176. 
Hollifield, B., A. Neklyudov, and C. Spatt. 2017. Bid-Ask Spreads, Trading Networks and the Pricing of Securitizations. Working Paper.

Hull, J. 2014. Options, Futures, and Other Derivatives. Prentice Hall.

Li, D., and N. Schrhoff. 2018. Dealer Networks. Journal of Finance .

Lin, L., and J. Surthi. 2013. Capital requirements for OTC Derivatives Central Counterparties. IMF Working Paper No. 13/3.

Loon, Y. C., and Z. K. Zhong. 2014. The impact of central clearing on counterparty risk, liquidity, and trading: Evidence from the credit default swap market. Journal of Financial Economics, $112: 91-115$.

Loon, Y. C., and Z. K. Zhong. 2016. Does Dodd-Frank affect OTC transaction costs and liquidity? Evidence from real-time CDS trade reports. Journal of Financial Economics, 119:645-672.

Manning, M., and D. Hughes. 2016. Central counterparties and banks: Vive la difference. Journal of Financial Market Infrastructures, 4:1-24.

Oehmke, M., and A. Zawadowski. 2016. The anatomy of the CDS market. Review of Financial Studies, 30:80-119.

Peltonen, T. A., M. Scheicher, and G. Vuillemey. 2014. The network structure of the CDS market and its determinants. Journal of Financial Stability, 13:118-133.

Sidanius, C., and F. Zikes. 2012. OTC derivatives reform and collateral demand impact. Bank of England Financial Stability Paper, No. 18.

Siriwardane, E. 2018. Limited Investment Capital and Credit Spreads. Journal of Finance . 


\section{Table 1. Results of cleaning procedure}

This table shows the number of observations that we lose at each of the cleaning steps described in section 3.1. Raw data set in TRs indicates the total number of observations before starting the cleaning procedure (i.e., the total number of observations after aggregating data coming from the four different TRs). Most observations are dropped when we set as a necessary requirement to have correctly reported LEI. The last two steps aim at dropping duplicate transactions repeated in the dataset due to double reporting. This is performed considering transactions with the same trade ID and same counterparties, but also considering transactions with the same values reported for the most important variables.

\begin{tabular}{lr}
\hline & Number of observations \\
Raw data set in TRs & $4,042,962$ \\
\hline Drop if: & $-1,031,768$ \\
\hline \hline Misreported counterparty (Non-LEI) & -325 \\
Missing notional & $-44,646$ \\
Implausible notional $<50 \mathrm{k}$ & -296 \\
Implausible notional $>10 \mathrm{bn}$ & $-44,221$ \\
Maturity: missing, $>2050$ or $<2018$ & $-36,085$ \\
Year of execution: missing, $<1970$ or $>2018$ & $-1,832$ \\
Missing counterparty side $(\mathrm{B} / \mathrm{S})$ & $-513,902$ \\
Keep only interest rate swaps & $-14,331$ \\
Non-identified counterparty & $-334,935$ \\
Intragroup & $-304,311$ \\
Duplicates - same LEI & $-49,821$ \\
Duplicates - same major variables & \\
\hline End result & $1,666,489$ \\
\hline
\end{tabular}


Table 2. Descriptive statistics on transaction data

This table shows the distribution of IRS-specific variables. The perspective is therefore at transaction level. It is divided into three different columns: the first column considers the overall sample of 1.7 million trades. The second and third columns consider, respectively, transactions in the cleared market, which covers $55 \%$ of the 1.7 million trades, and in the bilateral market, which covers the remaining $45 \%$. The variables reported: the Gross Notional; the Market Value; the Maturity Date, which indicats the year in which the contract is expiring; and the Maturity Years, which indicates the length of the contract, and which is computed as Maturity Date - Year of Execution; and finally, the Year of Execution of the contract.

\begin{tabular}{|c|c|c|c|}
\hline & Total Market & Cleared Market & Bilateral Market \\
\hline N Trades over Total & $100 \%$ & $55 \%$ & $44 \%$ \\
\hline Gross Notional - Total & $98.3 \mathrm{TN}$ & $70 \mathrm{TN}$ & $28 \mathrm{TN}$ \\
\hline Gross Notional - Mean & $58,980,000$ & $75,480,000$ & $38,520,000$ \\
\hline Gross Notional - Std Dev & $198,800,000$ & $237,600,000$ & $133,500,000$ \\
\hline Gross Notional - p25 & $6,000,000$ & $9,100,000$ & $3,946,000$ \\
\hline Gross Notional - Median & $19,130,000$ & $25,000,000$ & $11,700,000$ \\
\hline Gross Notional - p75 & $50,000,000$ & $62,490,000$ & $34,320,000$ \\
\hline Market Value - N Observations over Total & $88 \%$ & $49 \%$ & $39 \%$ \\
\hline Market Value - Mean & 85,369 & 19,152 & 143,568 \\
\hline Market Value - Std Dev & $13,500,00$ & $11,780,000$ & $15,380,000$ \\
\hline Market Value - p25 & $-5,006,000,000$ & $-210,991$ & $-230,294$ \\
\hline Market Value - Median & $-216,728$ & 0 & 2,522 \\
\hline Market Value - p75 & 1,071 & 210,497 & 323,562 \\
\hline Maturity Date - Mean & 2025 & 2025 & 2024 \\
\hline Maturity Date - Std Dev & 7 & 7 & 6 \\
\hline Maturity Date - p25 & 2020 & 2020 & 2019 \\
\hline Maturity Date - Median & 2022 & 2023 & 2022 \\
\hline Maturity Date - p75 & 2027 & 2027 & 2026 \\
\hline Maturity Years - Mean & 10 & 10 & 10 \\
\hline Maturity Years - Std Dev & 8 & 8 & 8 \\
\hline Maturity Years - p25 & 5 & 5 & 5 \\
\hline Maturity Years - Median & 8 & 8 & 8 \\
\hline Maturity Years - p75 & 12 & 11 & 12 \\
\hline Year of Execution - Mean & 2015 & 2016 & 2014 \\
\hline Year of Execution - Std Dev & 3 & 3 & 4 \\
\hline Year of Execution - p25 & 2014 & 2015 & 2013 \\
\hline Year of Execution - Median & 2016 & 2017 & 2015 \\
\hline Year of Execution - p75 & 2017 & 2017 & 2017 \\
\hline
\end{tabular}


Table 3. Descriptive statistics of banks' size, capital, and liquidity variables, and their correlation matrix

This table shows, in Panel A, the distribution of balance-sheet variables considered for the banks in our sample. Panel B shows the correlation matrix of such variables. The variables are considered to express the size, capital, and liquidity of a bank. The number of observations is lower for some variables due to missing data. Data are from balance sheets as of December 31, 2017, and are obtained from S\&P Global SNL Financial. The first variable considered is Total Assets. Two variables for banks' capital and leverage follow: these are the CET1 Ratio (calculated as CET1 over risk-weighted assets), the liquidity ratio (computed as liquid assets over total assets), and the Basel III leverage ratio (measured by CET1 over total exposure).

\begin{tabular}{|ccccccc|}
\hline VARIABLES & $\mathrm{N}$ & $\mathrm{mean}$ & $\mathrm{sd}$ & $\mathrm{p} 25$ & $\mathrm{p} 50$ & $\mathrm{p} 75$ \\
\hline \hline Total Assets & 147 & $401 \mathrm{BN}$ & $569 \mathrm{BN}$ & $41.6 \mathrm{BN}$ & $139 \mathrm{BN}$ & $565 \mathrm{BN}$ \\
CET1 Ratio & 137 & 16.4 & 6.3 & 12.7 & 14.9 & 17.9 \\
Leverage Ratio & 127 & 6.6 & 3.0 & 4.7 & 5.8 & 7.5 \\
Liquidity Ratio & 134 & 0.3 & 0.2 & 0.2 & 0.3 & 0.4 \\
\hline
\end{tabular}

\begin{tabular}{c|cccc} 
& Total Assets & CET1 Ratio & Leverage Ratio & Liquidity Ratio \\
\hline Total Assets & 1 & & & \\
CET1 Ratio & 0.35 & 1 & & \\
Leverage Ratio & -0.30 & -0.12 & 1 & 1 \\
Liquidity Ratio & -0.30 & 0.05 & 0.26 &
\end{tabular}


Table 4. Descriptive statistics of market activity measures at trader level

This table shows the distribution of main trade activity measures from a trader perspective. Panel A considers the cleared market, and Panel B the bilateral market. We first indicate the total number of counterparties trading in each market. The other variables are: Gross Notional, Net Notional, Number of Trades and Number of Counterparties. The distribution of each variable is computed from a trader perspective, meaning that the mean of the gross notional is the average gross notional of a trader in the cleared market and in the bilateral market (Panels A and B, respectively).

\begin{tabular}{|l|ccccc|}
\hline $\begin{array}{l}\text { Cleared Market } \\
\text { Total n. of counterparties: 174 }\end{array}$ & \multicolumn{5}{|c}{} \\
\hline \hline & mean & sd & p25 & p50 & p75 \\
\hline Gross Notional & $672 \mathrm{BN}$ & $4 \mathrm{TN}$ & $40 \mathrm{MN}$ & $882 \mathrm{MN}$ & $46.7 \mathrm{BN}$ \\
Net Notional & $107 \mathrm{BN}$ & $619.8 \mathrm{BN}$ & $7 \mathrm{MN}$ & $143 \mathrm{MN}$ & $5.1 \mathrm{BN}$ \\
Number of Trades & 8,895 & 50,814 & 12 & 65 & 928 \\
Number of Counterparties & 3 & 11 & 1 & 1 & 2 \\
& & & & & \\
\hline \hline
\end{tabular}

\begin{tabular}{|l|cccccc|}
\hline $\begin{array}{l}\text { Bilateral Market } \\
\text { Total n. of counterparties: 55,611 }\end{array}$ & \multicolumn{6}{|c}{} \\
\hline \hline & mean & sd & p25 & p50 & p75 \\
\hline Gross Notional & $1.4 \mathrm{BN}$ & $72 \mathrm{BN}$ & 566,658 & $2.2 \mathrm{MN}$ & $15 \mathrm{MN}$ \\
Net Notional & $288 \mathrm{BN}$ & $132 \mathrm{BN}$ & 500 & $196 \mathrm{MN}$ & $11 \mathrm{MN}$ \\
Number of Trades & 32 & 1.17 & 1 & 1 & 2 \\
Number of Counterparties & 3 & 64 & 1 & 1 & 1 \\
& & & & & \\
\hline \hline
\end{tabular}


Table 5. Counterparties' characteristics based on categorization

The table shows the sums and means of major characteristics for a counterparty, considering our allocation of the 282 fully identified counterparties in different categories. For dealers and intermediaries, a further distinction is made depending on whether they belong to the EMU (European Monetary Union) area or not. Dealers are the G-16 Dealers (i.e., the main 16 derivatives dealers). Intermediaries is a category defined by us of non-dealers that exhibit similar behaviour to dealers and are trading all different IRSs. For SSM banks (banks under the supervison of the European Central Bank) and other banks, a further distinction is made between clearing members and non-clearing members. The last three categories are non-banks, and then in a separate category, insurance companies and pension funds, and finally, the category including all CCPs. Each category contains the following number of counterparties: dealers 16, intermediaries EMU 6, intermediaries non-EMU 4, SSM banks clearing members 28, SSM banks non-clearing members 59, other banks clearing members 18 , other banks non-clearing members 28 , non-banks 98 , insurances and pension funds 14, CCPs 11.

\begin{tabular}{|c|c|c|c|c|c|c|c|}
\hline & $\begin{array}{c}\text { Gross } \\
\text { Notional } \\
\text { (sum) }\end{array}$ & $\begin{array}{c}\text { Net } \\
\text { Notional } \\
\text { (sum) }\end{array}$ & $\begin{array}{c}\text { Gross } \\
\text { Notional } \\
\text { (mean) }\end{array}$ & $\begin{array}{c}\text { Net } \\
\text { Notional } \\
\text { (mean - } \\
\text { absolute } \\
\text { values) } \\
\end{array}$ & $\begin{array}{c}\text { Net over } \\
\text { Gross ratio } \\
\text { (mean - } \\
\text { absolute } \\
\text { values) }\end{array}$ & $\begin{array}{c}\text { N. of } \\
\text { Counterparties } \\
(\text { mean })\end{array}$ & $\begin{array}{c}\text { Index } \\
\text { (mean) }\end{array}$ \\
\hline Dealers & $80.3 \mathrm{TN}$ & $12 \mathrm{TN}$ & $5 \mathrm{TN}$ & $939.6 \mathrm{BN}$ & $15 \%$ & 1401 & 26.75 \\
\hline Intermediaries EMU & $14 \mathrm{TN}$ & $-1.3 \mathrm{TN}$ & $2.3 \mathrm{TN}$ & $357 \mathrm{BN}$ & $14 \%$ & 3191 & 27.0 \\
\hline Intermediaries Non-EMU & $1.2 \mathrm{TN}$ & $-47.7 \mathrm{BN}$ & $310 \mathrm{BN}$ & $116 \mathrm{BN}$ & $37 \%$ & 201 & 27.0 \\
\hline Other Banks Clearing Members & $1.3 \mathrm{TN}$ & $-372 \mathrm{BN}$ & $72.6 \mathrm{BN}$ & $21.1 \mathrm{BN}$ & $32 \%$ & 67 & 19.4 \\
\hline Other Banks Non-Clearing Members & $2.3 \mathrm{TN}$ & $-571 \mathrm{BN}$ & $82.9 \mathrm{BN}$ & $46.4 \mathrm{BN}$ & $37 \%$ & 29 & 16.1 \\
\hline Non-Banks & $11.4 \mathrm{TN}$ & $-1 \mathrm{TN}$ & $116 \mathrm{BN}$ & $17.4 \mathrm{BN}$ & $35 \%$ & 15 & 10.9 \\
\hline Insurances Pensions & $904 \mathrm{BN}$ & $-41.2 \mathrm{BN}$ & $64.6 \mathrm{BN}$ & $8.3 \mathrm{BN}$ & $15 \%$ & 12 & 11.5 \\
\hline CCPs & $58.5 \mathrm{TN}$ & $-7.9 \mathrm{TN}$ & $5.3 \mathrm{TN}$ & $714 \mathrm{BN}$ & $20 \%$ & 23 & 8.4 \\
\hline
\end{tabular}

\begin{tabular}{|l|c|c|c|c|c|c|}
\hline & $\begin{array}{c}\text { Total } \\
\text { Assets } \\
\text { (mean) }\end{array}$ & $\begin{array}{c}\text { Liquid } \\
\text { Assets } \\
\text { (mean) }\end{array}$ & $\begin{array}{c}\text { Leverage } \\
\text { ratio } \\
\text { (mean) }\end{array}$ & $\begin{array}{c}\text { CET1 } \\
\text { Ratio } \\
\text { (mean) }\end{array}$ & $\begin{array}{c}\text { Gross Notional } \\
\text { over Total Assets } \\
\text { (mean) }\end{array}$ & $\begin{array}{c}\text { Net Notional } \\
\text { over Total Assets } \\
\text { (mean - absolute values) }\end{array}$ \\
\hline \hline Dealers & $1.3 \mathrm{TN}$ & $659 \mathrm{BN}$ & 5.5 & 13.8 & 3.5 & \\
Intermediaries EMU & $844 \mathrm{BN}$ & $233 \mathrm{BN}$ & 5.5 & 13.4 & 3.2 & 0.6 \\
Intermediaries Non-EMU & $987 \mathrm{BN}$ & $396 \mathrm{BN}$ & 4.3 & 13.3 & 0.6 & 0.6 \\
SSM Banks Clearing Members & $195 \mathrm{BN}$ & $63 \mathrm{BN}$ & 5.5 & 17.4 & 1.8 & 0.7 \\
SSM Banks Non-Clearing Members & $97.7 \mathrm{BN}$ & $31.3 \mathrm{BN}$ & 7.9 & 17.7 & 0.7 & \\
Other Banks Clearing Members & $454 \mathrm{BN}$ & $153.8 \mathrm{BN}$ & 5.8 & 14.4 & 0.6 & 0.1 \\
Other Banks Non-Clearing Members & $461 \mathrm{BN}$ & $128.6 \mathrm{BN}$ & 7.3 & 17.3 & 1.0 & - \\
Non-Banks & - & - & - & - & - & - \\
Insurances Pensions & - & - & - & - & - & - \\
CCPs & - & - & - & - & - & - \\
\hline
\end{tabular}




\section{Table 6. Market activity}

This table shows the results for the regression of the exposures. The regression investigates if the market activity is more influenced by certain categories. The dependent variable, (i.e., the exposure) is expressed in terms of the log value of the aggregate gross notional at counterparty level. We use an OLS estimation model. Explanatory variables are dummies indicating whether that counterparty belongs to a certain category $($ dummy $=1)$ or not (dummy $=0)$. The regression in column 1 follows the "traditional" categorization of the traders, mainly distinguishing between dealers and other banks and non-banks that are non-dealers. In column 2, we add a distinct category for the non-dealers that we identified as intermediaries. We show that adding this category adds significant contribution to the analysis. We control the effect of a counterparty being a clearing member by adding a further distinction between clearing members and non-clearing members. The reference group is SSM banks that are not clearing members. Test statistics, derived from standard errors clustered at counterparty level, are given in parentheses. The significance is indicated as follows: ${ }^{*}<0.1,{ }^{* *}<0.05,{ }^{* * *}<0.01$.

\begin{tabular}{c|c|c|} 
& $(1)$ & $(2)$ \\
VARIABLES & Log Gross Notional & Log Gross Notional \\
\hline \hline Dealers EMU & $6.793^{* * *}$ & $6.793^{* * *}$ \\
Dealers Non-EMU & $(0.393)$ & $(0.394)$ \\
Intermediaries EMU & $4.244^{* * *}$ & $4.244^{* * *}$ \\
& $(0.446)$ & $(0.448)$ \\
Intermediaries Non-EMU & & $4.992^{* * *}$ \\
& & $(0.331)$ \\
SSM Banks Clearing Members & $2.682^{* * *}$ & $2.785^{* * *}$ \\
Other Banks Clearing Members & $(0.460)$ & $(0.474)$ \\
& $1.419^{* * *}$ & $2.187^{* * *}$ \\
Other Banks Non-Clearing Members & $(0.443)$ & $(0.461)$ \\
& $0.820^{* *}$ & $\left(0.433^{* *}\right.$ \\
Non-Banks Clearing Members & $(0.381)$ & $0.820^{* *}$ \\
& $1.565^{* * *}$ & $(0.383)$ \\
Non-Banks Non-Clearing Members & $(0.586)$ & $1.529^{* *}$ \\
Constant & 0.434 & $(0.672)$ \\
& $(0.358)$ & 0.434 \\
Observations & $23.47^{* * *}$ & $(0.360)$ \\
& $(0.322)$ & $23.47^{* * *}$ \\
& 271 & $(0.323)$ \\
& 0.351 & 271 \\
& & 0.388 \\
& &
\end{tabular}




\section{Table 7. Specification at bank level}

This table shows the results for the regression on the specialisation of the banks in our sample. The dependent variable is the total gross notional of trader $\mathrm{k}$ divided into 12 different types of contracts based on a specific contract maturity bucket (1-3 years, 4-6 years, and 9-11 years) and cash flow structure (fixed-floating, fixed-fixed, and floating-floating). Columns 1, 2, and 3 distinguish three different regressions for three types of currencies: (1) Euro, (2) US Dollars, and (3) other currencies. The explanatory variables are dummy variables controlling for the different maturities of the contracts and dummies on a counterparty's category; in this specification, the focus is only on banks. The most important categories of dealers and intermediaries are now focusing only on EMU area dealers and intermediaries. Interaction variables are added to investigate whether a category is more specialised on certain maturities. SSM banks (i.e. banks under the supervision of the European Central Bank) are the reference group. Test statistics, derived from standard errors clustered at counterparty level, are given in parentheses. The significance is indicated as follows: * $<0.1,{ }^{* *}<0.05, * * *<0.01$.

\begin{tabular}{|c|c|c|c|}
\hline VARIABLES & $\begin{array}{c}(1) \\
\text { Log of } \\
\text { Gross Notional } \\
\text { EUR }\end{array}$ & $\begin{array}{c}(2) \\
\text { Log of } \\
\text { Gross Notional } \\
\text { USD }\end{array}$ & $\begin{array}{c}(3) \\
\text { Log of } \\
\text { Gross Notional } \\
\text { Other Currencies }\end{array}$ \\
\hline Dummy $1-3$ years & $\begin{array}{c}0.365 \\
(0.495)\end{array}$ & $\begin{array}{c}1.295^{* * *} \\
(0.416)\end{array}$ & $\begin{array}{c}0.917 * * \\
(0.429)\end{array}$ \\
\hline Dummy 5 years & $\begin{array}{c}0.913^{* *} \\
(0.401)\end{array}$ & $\begin{array}{c}1.247^{* * *} \\
(0.322)\end{array}$ & $\begin{array}{c}0.441 \\
(0.385)\end{array}$ \\
\hline Dummy 10 years & $\begin{array}{c}-1.093^{* * *} \\
(0.375)\end{array}$ & $\begin{array}{c}-0.999^{* * *} \\
(0.306)\end{array}$ & $\begin{array}{l}-0.326 \\
(0.324)\end{array}$ \\
\hline Dealers EMU & $\begin{array}{c}13.10^{* * *} \\
(0.696)\end{array}$ & $\begin{array}{c}18.05^{* * *} \\
(0.866)\end{array}$ & $\begin{array}{c}17.28^{* * *} \\
(1.780)\end{array}$ \\
\hline Dealers EMU * $1-3$ years & $\begin{array}{c}0.336 \\
(0.535)\end{array}$ & $\begin{array}{c}0.229 \\
(0.546)\end{array}$ & $\begin{array}{c}1.879 \\
(1.214)\end{array}$ \\
\hline Dealers EMU $* 5$ years & $\begin{array}{c}-0.925^{* *} \\
(0.414)\end{array}$ & $\begin{array}{l}-0.515 \\
(0.494)\end{array}$ & $\begin{array}{l}0.0385 \\
(0.424)\end{array}$ \\
\hline Dealers EMU $* 10$ years & $\begin{array}{c}0.905^{* *} \\
(0.396)\end{array}$ & $\begin{array}{l}1.024^{*} \\
(0.554)\end{array}$ & $\begin{array}{l}-0.454 \\
(0.445)\end{array}$ \\
\hline Intermediaries EMU & $\begin{array}{c}12.15^{* * *} \\
(0.674)\end{array}$ & $\begin{array}{c}15.13^{* * *} \\
(1.093)\end{array}$ & $\begin{array}{c}14.29^{* * *} \\
(1.237)\end{array}$ \\
\hline Intermediaries EMU $* 1-3$ years & $\begin{array}{c}0.132 \\
(0.510)\end{array}$ & $\begin{array}{l}-0.515 \\
(1.567)\end{array}$ & $\begin{array}{c}0.580 \\
(1.548)\end{array}$ \\
\hline Intermediaries EMU $* 5$ years & $\begin{array}{l}-0.764^{*} \\
(0.427)\end{array}$ & $\begin{array}{c}0.392 \\
(0.983)\end{array}$ & $\begin{array}{c}0.371 \\
(1.381)\end{array}$ \\
\hline Intermediaries $\mathrm{EMU} * 10$ years & $\begin{array}{l}-0.441 \\
(0.988)\end{array}$ & $\begin{array}{l}-0.532 \\
(1.129)\end{array}$ & $\begin{array}{l}-2.002^{*} \\
(1.095)\end{array}$ \\
\hline Other Banks & $\begin{array}{c}-3.434^{* * *} \\
(1.014)\end{array}$ & $\begin{array}{c}2.399^{* *} \\
(0.956)\end{array}$ & $\begin{array}{c}3.620^{* * *} \\
(1.045)\end{array}$ \\
\hline Other Banks * 1-3 years & $\begin{array}{l}1.873^{* *} \\
(0.932)\end{array}$ & $\begin{array}{c}2.022^{* * *} * \\
(0.771)\end{array}$ & $\begin{array}{l}1.250 \\
(0.768)\end{array}$ \\
\hline Other Banks * 5 years & $\begin{array}{c}0.526 \\
(0.786)\end{array}$ & $\begin{array}{c}0.169 \\
(0.694)\end{array}$ & $\begin{array}{l}1.232^{* *} \\
(0.599)\end{array}$ \\
\hline Other Banks * 10 years & $\begin{array}{c}0.250 \\
(0.648)\end{array}$ & $\begin{array}{c}0.108 \\
(0.611)\end{array}$ & $\begin{array}{l}-0.629 \\
(0.636)\end{array}$ \\
\hline Constant & $\begin{array}{c}10.22^{* * *} \\
(0.638)\end{array}$ & $\begin{array}{c}5.159^{* * *} \\
(0.558)\end{array}$ & $\begin{array}{c}4.067^{* * *} \\
(0.577)\end{array}$ \\
\hline $\begin{array}{c}\text { Observations } \\
\text { R-squared }\end{array}$ & $\begin{array}{l}1,776 \\
0.129\end{array}$ & $\begin{array}{l}1,776 \\
0.195\end{array}$ & $\begin{array}{l}1,776 \\
0.192\end{array}$ \\
\hline
\end{tabular}




\section{Table 8. Net exposure}

This table shows the results for the regression of the net exposures. Net exposure is expressed in two different ways in columns 1 and 2 . In column 1, it is the ratio computed as the net notional over the gross notional for every trader $\mathrm{k}$, in absolute value. In column 2 , it is the logarithm of the aggregate net notional in absolute value. Explanatory variables are dummies indicating whether that counterparty belongs to a certain category $($ dummy $=1)$ or not $($ dummy $=0)$. Standard errors are clustered at the counterparty level. This setup is different from the previous because we distinguish insurance companies and pension funds from non-banks. SSM banks (i.e., banks under the supervision of the European Central Bank) that are non-clearing members are the reference group. Test statistics, derived from standard errors clustered at counterparty level, are given in parentheses. The significance is indicated as follows: ${ }^{*}<0.1,{ }^{* *}<0.05,{ }^{* * *}<0.01$.

\begin{tabular}{c|c|c|} 
& $\begin{array}{c}(1) \\
\text { Absolute Net } \\
\text { Over Gross }\end{array}$ & $\begin{array}{c}(2) \\
\text { Absolute } \\
\text { Net Notional }\end{array}$ \\
\hline \hline & $-0.111^{* *}$ & $6.761^{* * *}$ \\
Dealers* EMU & $(0.0464)$ & $(0.438)$ \\
Dealers Non-EMU & $-0.174^{* * *}$ & $3.651^{* * *}$ \\
Intermediaries * EMU & $(0.0388)$ & $(0.454)$ \\
Intermediaries Non-EMU & $-0.162^{* * *}$ & $4.333^{* * *}$ \\
& $(0.0603)$ & $(0.517)$ \\
Other Banks Non-Clearing Members & 0.0695 & $3.399^{* * *}$ \\
Other Banks Clearing Members & $(0.0808)$ & $(0.526)$ \\
& 0.0652 & $1.041^{* *}$ \\
SSM Banks Clearing Members & $0.0626)$ & $(0.445)$ \\
& 0.0187 & $1.351^{* * *}$ \\
Non-Banks & $(0.0623)$ & $(0.451)$ \\
& $\left(0.140^{* * *}\right.$ & $1.236^{* * *}$ \\
Insurance Pension & $0.0434)$ & $(0.431)$ \\
& $(0.0456)$ & $(0.343)$ \\
Constant & $-0.155^{* * *}$ & -0.0302 \\
& $(0.0518)$ & $(0.600)$ \\
R-squared & $0.305^{* * *}$ & $21.81^{* * *}$ \\
& $(0.0347)$ & $(0.304)$ \\
& 271 & 271 \\
& 0.094 & 0.333
\end{tabular}


Table 9. Impact of bank size

This table shows the results for the regression investigating the impact of a bank's size on different exposure measures. The different measures considered for market activity are: log of total gross notional in column 1; the ratio computed as the net notional over the gross notional for every trader $\mathrm{k}$, in absolute value in column 2; the logarithm of the aggregate net notional in absolute value in column 3; and the logarithm of the aggregate net notional scaled over total assets in column 3. The explanatory variables follow the same setup as in Table 6, the only difference being that we do not consider non-banks (for reasons of balance-sheet data availability), and we add the variable expressing the size of a bank (i.e., the logarithm of total assets). Data are from 31/12/2017 and are obtained from S\&P Global SNL Financial. Test statistics, derived from standard errors clustered at counterparty level, are given in parentheses. The significance is indicated as follows: ${ }^{*}<0.1,{ }^{* *}$ $<0.05, * * *<0.01$.

\begin{tabular}{|c|c|c|c|c|}
\hline VARIABLES & $\begin{array}{c}(1) \\
\text { Log of } \\
\text { Gross Notional }\end{array}$ & $\begin{array}{c}(2) \\
\text { Absolute Net over } \\
\text { Gross Ratio } \\
\end{array}$ & $\begin{array}{c}(3) \\
\text { Log of Absolute } \\
\text { Net Notional }\end{array}$ & $\begin{array}{c}(4) \\
\text { Net Notional } \\
\text { / Total Assets }\end{array}$ \\
\hline Dealers EMU & $\begin{array}{c}3.700 * * * \\
(0.568)\end{array}$ & $\begin{array}{l}-0.0768 \\
(0.0772)\end{array}$ & $\begin{array}{c}4.002^{* * *} \\
(0.582)\end{array}$ & $\begin{array}{c}2.387^{* *} \\
(0.920)\end{array}$ \\
\hline Dealers Non-EMU & $\begin{array}{c}1.511^{* * *} \\
(0.556)\end{array}$ & $\begin{array}{l}-0.142^{* *} \\
(0.0664)\end{array}$ & $\begin{array}{l}1.221^{* *} \\
(0.530)\end{array}$ & $\begin{array}{l}0.389^{*} \\
(0.207)\end{array}$ \\
\hline Intermediaries EMU & $\begin{array}{c}2.528^{* * *} \\
(0.455)\end{array}$ & $\begin{array}{l}-0.131^{*} \\
(0.0780)\end{array}$ & $\begin{array}{c}2.149^{* * *} \\
(0.616)\end{array}$ & $\begin{array}{c}0.780^{* *} \\
(0.393)\end{array}$ \\
\hline Intermediaries Non-EMU & $\begin{array}{c}0.595 \\
(0.662)\end{array}$ & $\begin{array}{c}0.142 \\
(0.104)\end{array}$ & $\begin{array}{c}1.609^{* * *} \\
(0.553)\end{array}$ & $\begin{array}{c}0.421^{* *} \\
(0.202)\end{array}$ \\
\hline Other Banks Non-Clearing Members & $\begin{array}{c}0.142 \\
(0.415)\end{array}$ & $\begin{array}{c}0.0993 \\
(0.0633)\end{array}$ & $\begin{array}{c}0.518 \\
(0.473)\end{array}$ & $\begin{array}{l}0.402^{*} \\
(0.217)\end{array}$ \\
\hline Other Banks Clearing Members & $\begin{array}{l}-0.259 \\
(0.512)\end{array}$ & $\begin{array}{c}0.0435 \\
(0.0681)\end{array}$ & $\begin{array}{c}0.146 \\
(0.411)\end{array}$ & $\begin{array}{c}0.138 \\
(0.116)\end{array}$ \\
\hline SSM Banks Clearing Members & $\begin{array}{c}1.341^{* * *} \\
(0.348)\end{array}$ & $\begin{array}{l}-0.118^{* *} \\
(0.0548)\end{array}$ & $\begin{array}{c}0.530 \\
(0.377)\end{array}$ & $\begin{array}{c}0.209 \\
(0.130)\end{array}$ \\
\hline Log of Total Assets & $\begin{array}{c}0.903^{* * *} \\
(0.145)\end{array}$ & $\begin{array}{r}-0.00488 \\
(0.0198)\end{array}$ & $\begin{array}{c}0.825^{* * *} \\
(0.134)\end{array}$ & $\begin{array}{l}-0.118^{*} \\
(0.0643)\end{array}$ \\
\hline Constant & $\begin{array}{l}1.180 \\
(3.627)\end{array}$ & $\begin{array}{l}0.408 \\
(0.495)\end{array}$ & $\begin{array}{l}1.375 \\
(3.372)\end{array}$ & $\begin{array}{l}3.037^{*} \\
(1.579)\end{array}$ \\
\hline $\begin{array}{l}\text { Observations } \\
\text { R-squared }\end{array}$ & $\begin{array}{c}147 \\
0.665\end{array}$ & $\begin{array}{c}147 \\
0.132\end{array}$ & $\begin{array}{c}147 \\
0.598\end{array}$ & $\begin{array}{c}147 \\
0.327\end{array}$ \\
\hline
\end{tabular}


Table 10. Impact of banks' capital and liquidity

This table shows the results for the regression investigating the impact of a bank capital and liquidity on different exposure measures. The different measures considered for market activity are: $\log$ of total gross notional in column 1; the ratio computed as the net notional over the gross notional for every trader $\mathrm{k}$ in absolute value in column 2; the logarithm of the aggregate net notional in absolute value in column 3; and the logarithm of the aggregate net notional scaled over total assets in column 3. The explanatory variables follow the same setup as in Table 9, the only difference being that we now add the variable expressing the of a bank's capital and liquidity (i.e., the CET1 ratio, calculated as CET1 over risk-weighted assets; the liquidity ratio, computed as liquid assets over total assets; and the Basel III leverage ratio, measured by CET1 over total exposure). An interaction variable investigating the combined effect of the leverage ratio and the total assets is added in the second column of each specification. Data are from 31/12/2017 and are obtained from S\&P Global SNL Financial. Test statistics, derived from standard errors clustered at counterparty level, are given in parentheses. The significance is indicated as follows: ${ }^{*}<0.1, * *<0.05$, $* * *$ $<0.01$.

\begin{tabular}{|c|c|c|c|c|c|c|c|c|}
\hline VARIABLES & $\begin{array}{c}(1) \\
\text { Log of } \\
\text { Gross } \\
\text { Notional }\end{array}$ & $\begin{array}{c}(2) \\
\text { Log of } \\
\text { Gross } \\
\text { Notional }\end{array}$ & $\begin{array}{c}(3) \\
\text { Absolute } \\
\text { Net over } \\
\text { Gross Ratio }\end{array}$ & $\begin{array}{c}(4) \\
\text { Absolute } \\
\text { Net over } \\
\text { Gross Ratio }\end{array}$ & $\begin{array}{c}(5) \\
\text { Log of } \\
\text { Absolute } \\
\text { Net Notional }\end{array}$ & $\begin{array}{c}(6) \\
\text { Log of } \\
\text { Absolute } \\
\text { Net Notional }\end{array}$ & $\begin{array}{c}(7) \\
\text { Net } \\
\text { Notional/ } \\
\text { Total Assets }\end{array}$ & $\begin{array}{c}(8) \\
\text { Net } \\
\text { Notional/ } \\
\text { Total Assets }\end{array}$ \\
\hline Dealers EMU & $\begin{array}{c}2.638^{* * *} * \\
(0.702)\end{array}$ & $\begin{array}{c}3.043^{* * *} \\
(0.735)\end{array}$ & $\begin{array}{c}0.0475 \\
(0.0985)\end{array}$ & $\begin{array}{l}0.0373 \\
(0.101)\end{array}$ & $\begin{array}{c}3.513^{* * *} \\
(0.745)\end{array}$ & $\begin{array}{c}4.013^{* * *} \\
(0.799)\end{array}$ & $\begin{array}{c}2.039^{* *} \\
(0.900)\end{array}$ & $\begin{array}{c}2.095^{* *} \\
(0.895)\end{array}$ \\
\hline Dealers Non-EMU & $\begin{array}{c}0.631 \\
(0.678)\end{array}$ & $\begin{array}{c}0.514 \\
(0.697)\end{array}$ & $\begin{array}{c}-0.0312 \\
(0.0796)\end{array}$ & $\begin{array}{c}-0.0283 \\
(0.0796)\end{array}$ & $\begin{array}{c}1.024 \\
(0.669)\end{array}$ & $\begin{array}{c}0.880 \\
(0.734)\end{array}$ & $\begin{array}{c}0.164 \\
(0.277)\end{array}$ & $\begin{array}{c}0.148 \\
(0.283)\end{array}$ \\
\hline Intermediaries EMU & $\begin{array}{c}2.119^{* * *} * \\
(0.472)\end{array}$ & $\begin{array}{c}2.283^{* * *} \\
(0.445)\end{array}$ & $\begin{array}{l}-0.0556 \\
(0.0884)\end{array}$ & $\begin{array}{l}-0.0597 \\
(0.0893)\end{array}$ & $\begin{array}{c}1.905^{* * *} \\
(0.696)\end{array}$ & $\begin{array}{c}2.108^{* * *} \\
(0.703)\end{array}$ & $\begin{array}{l}0.753^{*} \\
(0.425)\end{array}$ & $\begin{array}{l}0.776^{*} \\
(0.426)\end{array}$ \\
\hline Intermediaries Non-EMU & $\begin{array}{c}-0.177 \\
(0.741)\end{array}$ & $\begin{array}{c}0.323 \\
(0.676)\end{array}$ & $\begin{array}{c}0.244^{* *} \\
(0.112)\end{array}$ & $\begin{array}{c}0.231^{* *} \\
(0.115)\end{array}$ & $\begin{array}{c}1.217^{* *} \\
(0.613)\end{array}$ & $\begin{array}{c}1.836^{* * *} \\
(0.586)\end{array}$ & $\begin{array}{c}0.217 \\
(0.242)\end{array}$ & $\begin{array}{c}0.286 \\
(0.236)\end{array}$ \\
\hline Other Banks Non-Clearing Members & $\begin{array}{l}-0.176 \\
(0.607)\end{array}$ & $\begin{array}{c}-0.453 \\
(0.565)\end{array}$ & $\begin{array}{c}0.0480 \\
(0.0699)\end{array}$ & $\begin{array}{c}0.0550 \\
(0.0738)\end{array}$ & $\begin{array}{c}0.177 \\
(0.647)\end{array}$ & $\begin{array}{l}-0.165 \\
(0.622)\end{array}$ & $\begin{array}{c}0.221 \\
(0.342)\end{array}$ & $\begin{array}{c}0.183 \\
(0.347)\end{array}$ \\
\hline Other Banks Clearing Members & $\begin{array}{c}-0.401 \\
(0.552)\end{array}$ & $\begin{array}{l}-0.229 \\
(0.525)\end{array}$ & $\begin{array}{c}0.108 \\
(0.0787)\end{array}$ & $\begin{array}{c}0.104 \\
(0.0793)\end{array}$ & $\begin{array}{c}0.250 \\
(0.421)\end{array}$ & $\begin{array}{c}0.463 \\
(0.412)\end{array}$ & $\begin{array}{l}0.0377 \\
(0.151)\end{array}$ & $\begin{array}{l}0.0614 \\
(0.154)\end{array}$ \\
\hline SSM Banks Clearing Members & $\begin{array}{c}1.110^{* * *} \\
(0.363)\end{array}$ & $\begin{array}{c}1.029^{* * *} \\
(0.369)\end{array}$ & $\begin{array}{c}-0.0893^{*} \\
(0.0498)\end{array}$ & $\begin{array}{c}-0.0873^{*} \\
(0.0489)\end{array}$ & $\begin{array}{c}0.338 \\
(0.415)\end{array}$ & $\begin{array}{c}0.237 \\
(0.417)\end{array}$ & $\begin{array}{c}0.105 \\
(0.0997)\end{array}$ & $\begin{array}{c}0.0938 \\
(0.0983)\end{array}$ \\
\hline Log of Total Assets & $\begin{array}{c}1.052^{* * *} \\
(0.170)\end{array}$ & $\begin{array}{c}0.248 \\
(0.301)\end{array}$ & $\begin{array}{l}-0.0220 \\
(0.0220)\end{array}$ & $\begin{array}{c}-0.00173 \\
(0.0585)\end{array}$ & $\begin{array}{c}0.911^{* * * *} \\
(0.170)\end{array}$ & $\begin{array}{r}-0.0827 \\
(0.374)\end{array}$ & $\begin{array}{c}-0.123 \\
(0.0880)\end{array}$ & $\begin{array}{c}-0.233^{*} \\
(0.126)\end{array}$ \\
\hline CET1 Ratio & $\begin{array}{c}0.0471^{* *} \\
(0.0233)\end{array}$ & $\begin{array}{c}0.0494^{* *} \\
(0.0244)\end{array}$ & $\begin{array}{l}-0.00425 \\
(0.00275)\end{array}$ & $\begin{array}{c}-0.00431 \\
(0.00279)\end{array}$ & $\begin{array}{c}0.0397^{*} \\
(0.0223)\end{array}$ & $\begin{array}{c}0.0426^{*} \\
(0.0238)\end{array}$ & $\begin{array}{c}0.00161 \\
(0.00637)\end{array}$ & $\begin{array}{c}0.00193 \\
(0.00658)\end{array}$ \\
\hline Liquidity Ratio & $\begin{array}{c}1.424 \\
(1.397)\end{array}$ & $\begin{array}{c}2.290 \\
(1.485)\end{array}$ & $\begin{array}{r}-0.0937 \\
(0.192)\end{array}$ & $\begin{array}{l}-0.116 \\
(0.205)\end{array}$ & $\begin{array}{c}0.445 \\
(1.484)\end{array}$ & $\begin{array}{c}1.515 \\
(1.589)\end{array}$ & $\begin{array}{c}0.942 \\
(0.617)\end{array}$ & $\begin{array}{c}1.062 \\
(0.670)\end{array}$ \\
\hline Leverage Ratio & $\begin{array}{c}-0.119^{* *} \\
(0.0516)\end{array}$ & $\begin{array}{c}-3.074^{* * *} \\
(0.920)\end{array}$ & $\begin{array}{c}0.0116 \\
(0.00936)\end{array}$ & $\begin{array}{c}0.0861 \\
(0.215)\end{array}$ & $\begin{array}{c}-0.0937 \\
(0.0716)\end{array}$ & $\begin{array}{c}-3.745^{* * *} \\
-1.396\end{array}$ & $\begin{array}{l}-0.0295 \\
(0.0191)\end{array}$ & $\begin{array}{l}-0.436 \\
(0.347)\end{array}$ \\
\hline Log of Tot Assets * Lev Ratio & & $\begin{array}{c}0.119 * * * \\
(0.0373)\end{array}$ & & $\begin{array}{l}-0.00300 \\
(0.00870)\end{array}$ & & $\begin{array}{c}0.147^{* *} \\
(0.0565)\end{array}$ & & $\begin{array}{c}0.0164 \\
(0.0140)\end{array}$ \\
\hline Constant & $\begin{array}{l}-2.783 \\
(4.539)\end{array}$ & $\begin{array}{l}17.11^{* *} \\
(7.484)\end{array}$ & $\begin{array}{c}0.819 \\
(0.590)\end{array}$ & $\begin{array}{c}0.317 \\
(1.445)\end{array}$ & $\begin{array}{l}-0.875 \\
(4.643)\end{array}$ & $\begin{array}{c}23.71^{* *} \\
(9.274)\end{array}$ & $\begin{array}{c}3.114 \\
(2.333)\end{array}$ & $\begin{array}{l}5.849^{*} \\
(3.173)\end{array}$ \\
\hline $\begin{array}{l}\text { Observations } \\
\text { R-squared }\end{array}$ & $\begin{array}{c}117 \\
0.769\end{array}$ & $\begin{array}{c}117 \\
0.786\end{array}$ & $\begin{array}{c}117 \\
0.202\end{array}$ & $\begin{array}{c}117 \\
0.204\end{array}$ & $\begin{array}{c}117 \\
0.696\end{array}$ & $\begin{array}{c}117 \\
0.724\end{array}$ & $\begin{array}{c}117 \\
0.381\end{array}$ & $\begin{array}{c}117 \\
0.385\end{array}$ \\
\hline
\end{tabular}


Figure 1. Frequency of contracts' main features

This figure shows the frequency of three major features for IRS contracts: cash flow structure, maturity, and currency. Panel A shows the frequency of cash flow structure (i.e., the frequency of contracts exchanging fixed for fixed rates, fixed for floating, and floating for floating), and "." indicates the transactions for which it was not possible to identify the type of contract due to missing data. Panel B shows the frequency of the different currencies, and "."indicates the transactions for which it was not possible to identify the currency due to missing data. Panel C shows the frequency of the different maturities. The sample is from April 1, 2017, through March 30,2018 .
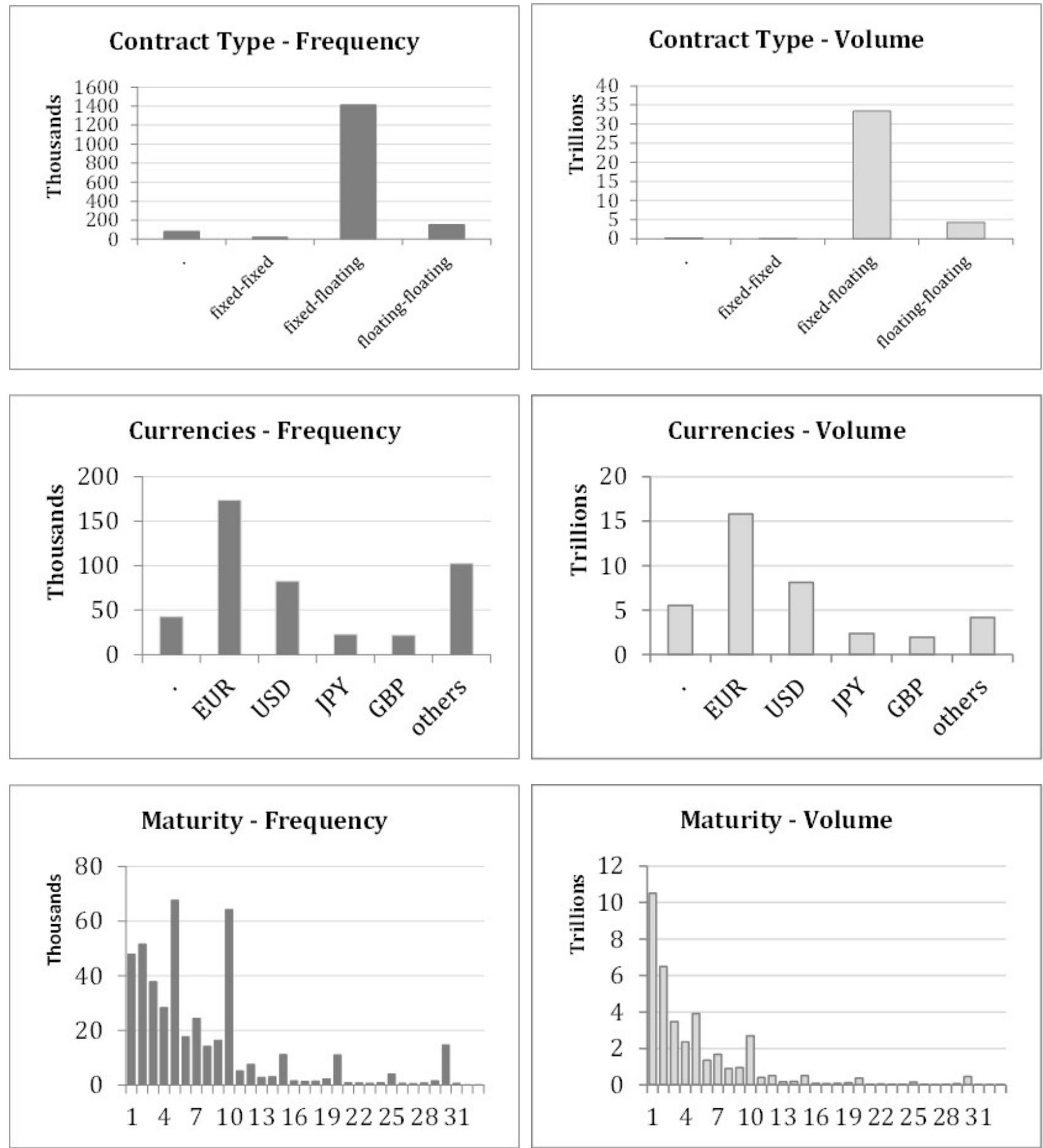
Figure 2. Network chart from SSM banks' perspective

This figure shows a stylized chart of the network with all major categories of firms in our sample from the perspective of the supervised euro area banks.

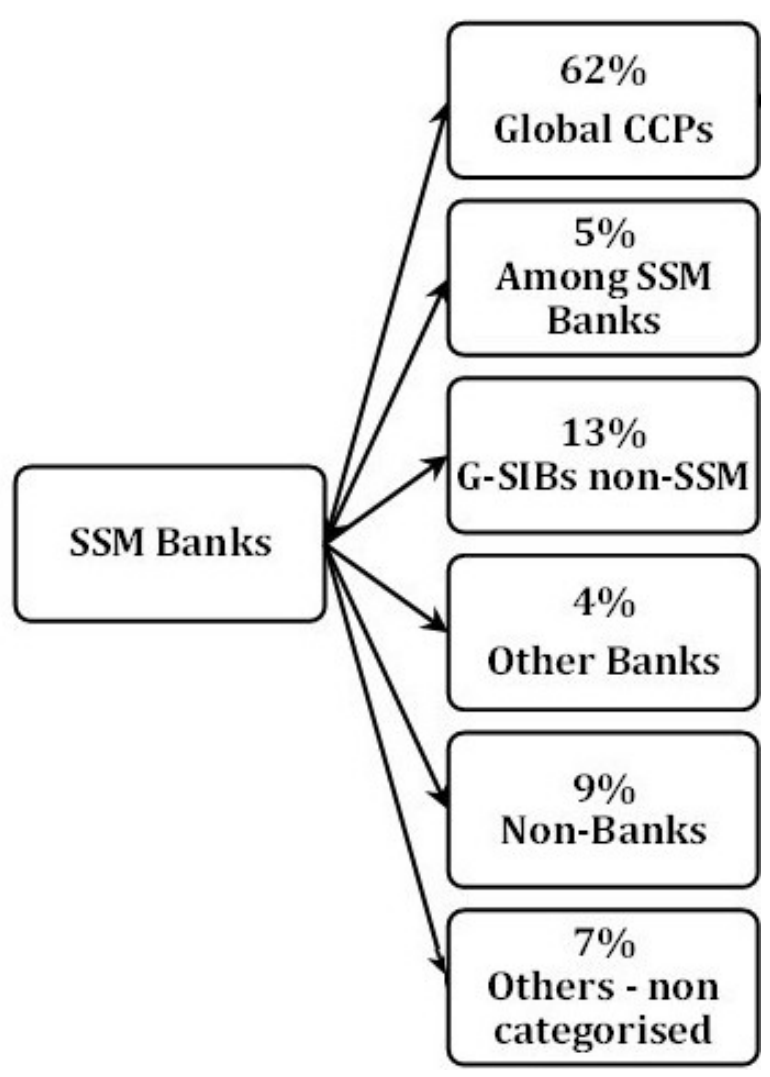




\section{Figure 3. Network matrix}

This figure shows the network structure of the euro area IRS market by means of a plot of two matrices. In Panel A we show the network matrix among 1,000 counterparties, in Panel B among the major 250 counterparties. In both matrices, element $\mathrm{G}(\mathrm{i} ; \mathrm{j})$ equals one if $\mathrm{i}$ and $\mathrm{j}$ have a non-zero bilateral exposure. Counterparties are ordered by their total gross exposure, highest to lowest, starting with the biggest dealers located in the bottom-left corner. Each dot, G, in the chart indicates the presence of a link between counterparty $i$ and $j$.
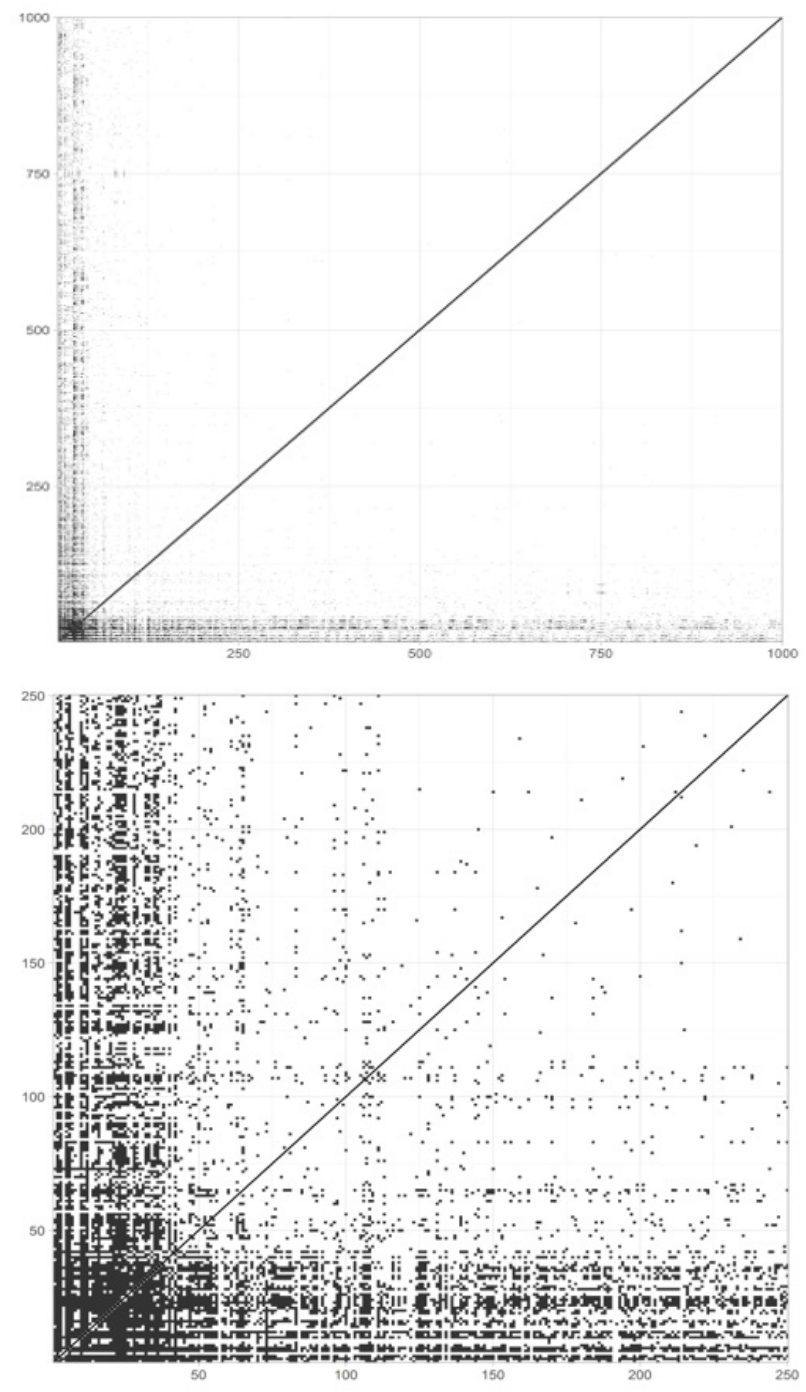
Figure 4. Gross notional versus number of counterparties for SSM banks

This figure shows a scatter plot that relates, for each counterparty, the total exposure (i.e., total gross notional) in the $\mathrm{Y}$ axis and the number of counterparties of that counterparty in the $\mathrm{X}$ axis. We focus on SSM banks (banks under the supervision of the European Central Bank). For reasons of data confidentiality, we cannot show single entities as single points; therefore we regroup different counterparties located in three different areas of the scatter plot. The dark blue area marked with the number 3 is the area where dealers are (those with the highest exposures and the highest number of counterparties); the blue area marked as 2 is where intermediaries are; and the light blue area marked with the number 1 is where all other banks are.

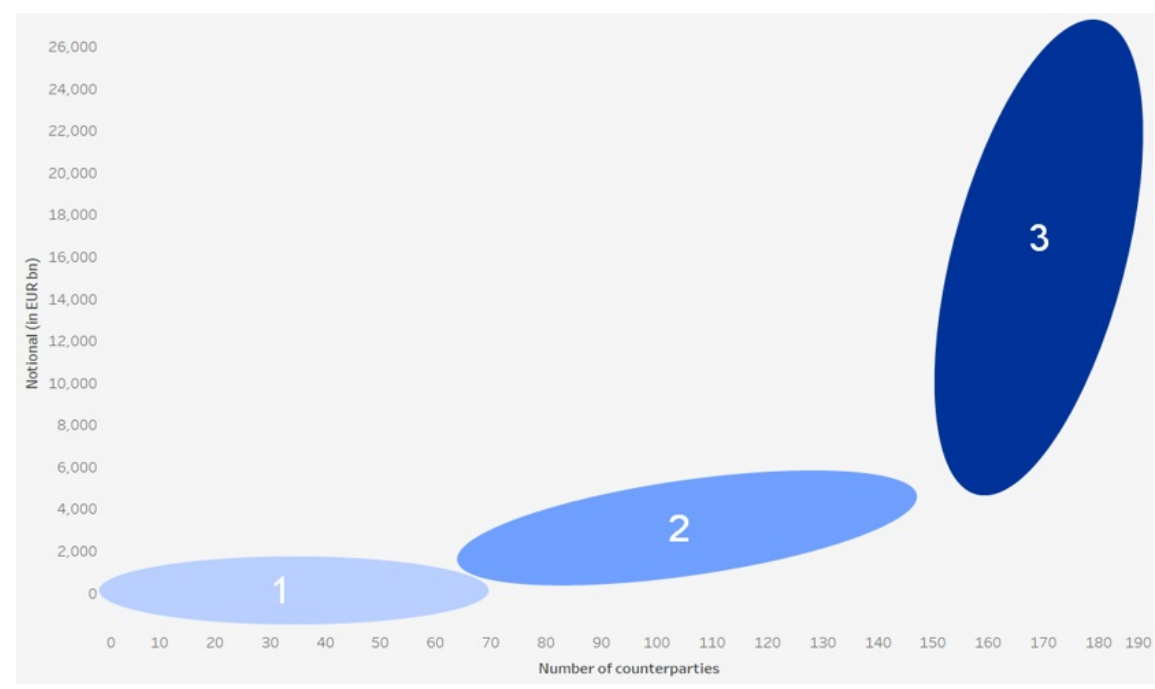


Figure 5. Breakdown of gross exposure among market participants before and after clearing obligation

This figure illustrates the changes for "who trades with whom" before and after clearing obligation. The different market categories are determined under the following categorization: dealers are the G-16 derivatives dealers, intermediaries are the 10 non-dealer banks that we identified as intermediaries based on their role in the market, others are all other banks and non-banks that are non-dealers and non-intermediaries, and CCPs are the 11 global CCPs in our sample.

\section{Before Clearing Obligation}

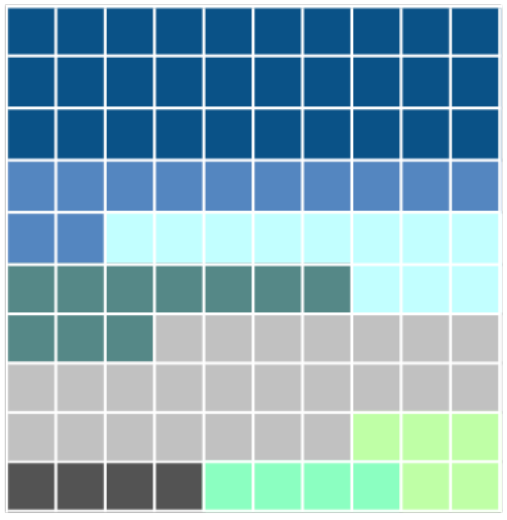

Dealers - CCP

Intermediaries - CCP

Others - CCP

Dealers - Dealers

Dealers - Others

Dealers - Intermediaries

Intermediaries - Others

Others - Others

\section{After Clearing Obligation}

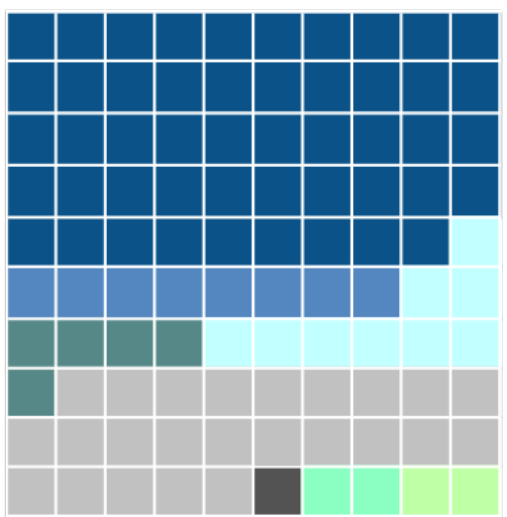

Dealers - CCP

Intermediaries - CCP

Others - CCP

Dealers - Dealers

Dealers - Others

Dealers - Intermediaries

Intermediaries - Others

Others - Others 
Figure 6. Net over gross ratio at counterparty level

This figure shows the single net over gross ratios distributed from the lowest $(-100 \%)$ to the highest $(+100 \%)$ for each counterparty. Counterparties with a ratio close to $+/-100 \%$ are the ones with higher exposure on one side of the market (fixed or floating). These are other banks (meaning non-dealers, non-intermediaries, and non-euro area banks) and non-banks. Counterparties with a ratio closer to zero are the ones more active in both sides of the contracts; these are mainly dealers, intermediaries, and CCPs.

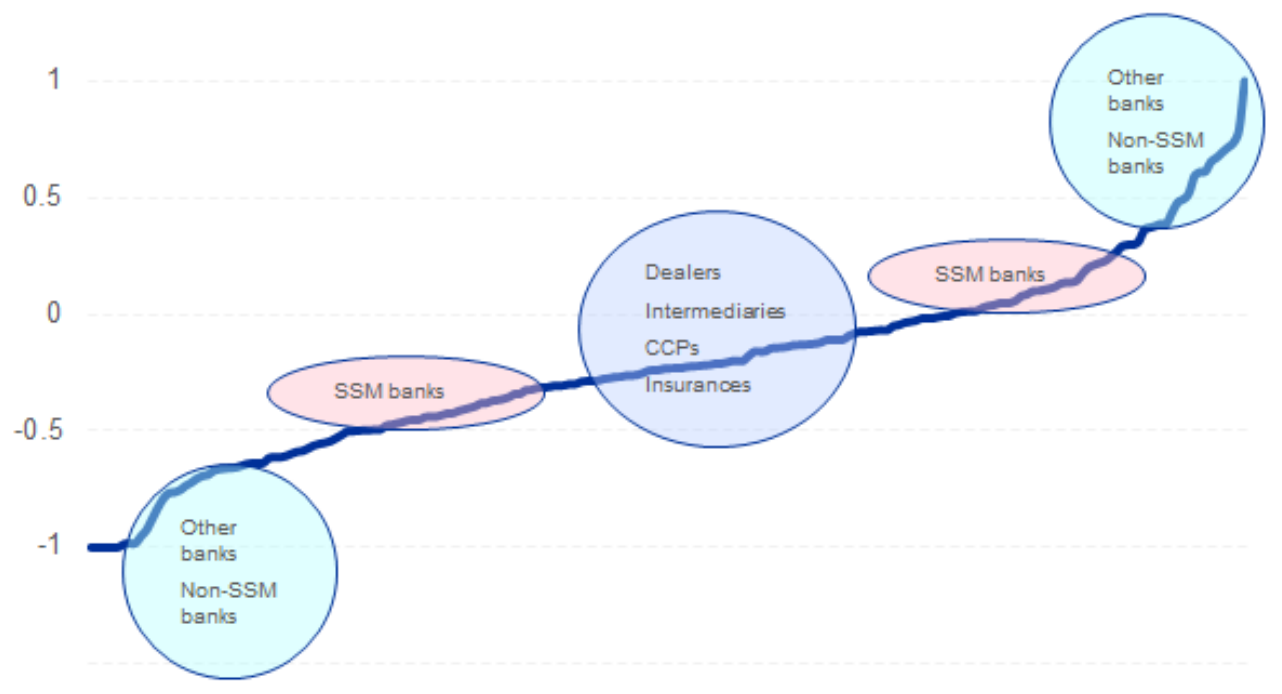




\section{Online appendix: Material available upon request}

Table 11. Robustness Check 1: Cross-sectional regression on market activity with September 2017 sample

\begin{tabular}{c|c|c|} 
& $(1)$ & $(2)$ \\
VARIABLES & $\begin{array}{c}\text { Log of } \\
\text { Gross Notional }\end{array}$ & $\begin{array}{c}\text { Log } \\
\text { Gross Notional }\end{array}$ \\
\hline \hline & & \\
Dealers EMU & $\left(0.399^{* * *}\right.$ & $6.688^{* * *}$ \\
Dealers Non-EMU & $4.227^{* * *}$ & $(0.348)$ \\
& $(0.385)$ & $\left(0.315^{* * *}\right.$ \\
Intermediaries EMU & & $4.942^{* * *}$ \\
Intermediaries Non-EMU & & $(0.293)$ \\
& & $3.436^{* * *}$ \\
Other Banks Non-Clearing Members & $0.979^{*}$ & $(0.270)$ \\
Other Banks Clearing Members & $(0.499)$ & $1.068^{* *}$ \\
SSM Banks Clearing Members & $1.771^{* * *}$ & $(0.496)$ \\
& $(0.322)$ & $\left(0.360^{* * *}\right.$ \\
Non-Banks Non-Clearing Members & $2.898^{* * *}$ & $2.632^{* * *}$ \\
Non-Banks Clearing Members & $(0.393)$ & $(0.395)$ \\
& 0.432 & 0.520 \\
Constant & $(0.351)$ & $(0.345)$ \\
& $1.116^{* *}$ & $1.204^{* * *}$ \\
Observations & $(0.438)$ & $(0.434)$ \\
& $23.63^{* * *}$ & $23.54^{* * *}$ \\
& $(0.278)$ & $(0.270)$ \\
& 208 & 208 \\
& 0.433 & 0.479 \\
& &
\end{tabular}


Table 12. Robustness Check 2: Regression on risk absorption considering only Fixed-Floating contracts

\begin{tabular}{|c|c|c|}
\hline VARIABLES & $\begin{array}{c}(1) \\
\text { Absolute } \\
\text { Net over Gross }\end{array}$ & $\begin{array}{c}(2) \\
\text { Abolute } \\
\text { Net Notional }\end{array}$ \\
\hline Dealers EMU & $\begin{array}{c}-0.138^{* * *} \\
(0.0474)\end{array}$ & $\begin{array}{c}6.585^{* * *} \\
(0.467)\end{array}$ \\
\hline Dealers Non-EMU & $\begin{array}{c}-0.207^{* * *} \\
(0.0376)\end{array}$ & $\begin{array}{c}3.367^{* * *} \\
(0.474)\end{array}$ \\
\hline Intermediaries EMU & $\begin{array}{c}-0.157^{* * *} \\
(0.0543)\end{array}$ & $\begin{array}{c}4.252^{* * *} \\
(0.610)\end{array}$ \\
\hline Intermediaries Non-EMU & $\begin{array}{l}-0.0871 \\
(0.0767)\end{array}$ & $\begin{array}{c}2.790^{* * *} \\
(0.603)\end{array}$ \\
\hline SSM Banks Clearing Members & $\begin{array}{c}-0.142^{* * *} \\
(0.0473)\end{array}$ & $\begin{array}{c}1.534^{* * *} \\
(0.409)\end{array}$ \\
\hline Other Banks Clearing Members & $\begin{array}{c}-0.0937^{*} \\
(0.0502)\end{array}$ & $\begin{array}{c}1.080^{* *} \\
(0.466)\end{array}$ \\
\hline Other Banks Non-Clearing Members & $\begin{array}{c}0.00641 \\
(0.0582)\end{array}$ & $\begin{array}{c}0.946^{* *} \\
(0.450)\end{array}$ \\
\hline Non-Banks & $\begin{array}{c}-0.0113 \\
(0.0451)\end{array}$ & $\begin{array}{c}0.470 \\
(0.348)\end{array}$ \\
\hline Insurances Pensions & $\begin{array}{c}-0.149 * * * \\
(0.0499)\end{array}$ & $\begin{array}{c}-0.0201 \\
(0.584)\end{array}$ \\
\hline Constant & $\begin{array}{c}0.278^{* * * *} \\
(0.0366)\end{array}$ & $\begin{array}{c}21.61^{* * *} \\
(0.308)\end{array}$ \\
\hline $\begin{array}{l}\text { Observations } \\
\text { R-squared }\end{array}$ & $\begin{array}{c}271 \\
0.079\end{array}$ & $\begin{array}{c}271 \\
0.314\end{array}$ \\
\hline
\end{tabular}


Table 13. Robustness Check 3: Regression on trade activity without considering the role of Non Euro Intermediaries

\begin{tabular}{|c|c|c|}
\hline VARIABLES & $\begin{array}{c}(1) \\
\text { Log of Gross Notional } \\
\text { Gross Notional }\end{array}$ & $\begin{array}{c}(2) \\
\text { Log of Gross Notional } \\
\text { Gross Notional }\end{array}$ \\
\hline Dealer EMU & $\begin{array}{c}6.777^{* * *} \\
(0.390)\end{array}$ & $\begin{array}{c}6.793^{* * *} \\
(0.394)\end{array}$ \\
\hline Dealers Non-EMU & $\begin{array}{c}4.228^{* * *} \\
(0.443)\end{array}$ & $\begin{array}{c}4.244^{* * *} \\
(0.447)\end{array}$ \\
\hline Intermediaries EMU & & $\begin{array}{c}4.992^{* * *} \\
(0.331)\end{array}$ \\
\hline SSM Banks Clearing Members & $\begin{array}{c}2.666^{* * *} \\
(0.457)\end{array}$ & $\begin{array}{c}2.187^{* * *} \\
(0.461)\end{array}$ \\
\hline Other Banks Clearing Members & $\begin{array}{c}1.357^{* * *} * \\
(0.425)\end{array}$ & $\begin{array}{c}1.434^{* * *} \\
(0.435)\end{array}$ \\
\hline Other Banks Non-Clearing Members & $\begin{array}{c}0.804^{* *} \\
(0.378)\end{array}$ & $\begin{array}{c}0.820^{* *} \\
(0.382)\end{array}$ \\
\hline Non-Banks Clearing Members & $\begin{array}{l}1.322^{* *} \\
(0.586)\end{array}$ & $\begin{array}{l}1.529^{* *} \\
(0.671)\end{array}$ \\
\hline Non-Banks Non-Clearing Members & $\begin{array}{c}0.418 \\
(0.355)\end{array}$ & $\begin{array}{c}0.434 \\
(0.359)\end{array}$ \\
\hline Constant & $\begin{array}{c}23.49^{* * *} \\
(0.318)\end{array}$ & $\begin{array}{c}23.47^{* * *} \\
(0.322)\end{array}$ \\
\hline $\begin{array}{l}\text { Observations } \\
\text { R-squared }\end{array}$ & $\begin{array}{c}271 \\
0.350\end{array}$ & $\begin{array}{c}271 \\
0.381\end{array}$ \\
\hline
\end{tabular}


Table 14. Robustness Check 4: specialisation - currency

\begin{tabular}{|c|c|}
\hline VARIABLES & Log of Gross Notional \\
\hline Dealers EMU & $\begin{array}{c}10.61^{* * *} \\
(0.848)\end{array}$ \\
\hline Dealers EMU $*$ EURO & $\begin{array}{c}\mathbf{0 . 4 1 5} \\
(0.282)\end{array}$ \\
\hline Dealers Non-EMU & $\begin{array}{c}8.106^{* * *} \\
(0.849)\end{array}$ \\
\hline Intermediaries EMU & $\begin{array}{c}8.044^{* * *} \\
(0.828)\end{array}$ \\
\hline Intermediaries EMU * EURO & $\begin{array}{c}\mathbf{1 . 8 8 1} * * * \\
(0.286)\end{array}$ \\
\hline Intermediaries Non-EMU & $\begin{array}{c}6.555^{* * *} \\
(0.862)\end{array}$ \\
\hline SSM Banks Clearing Members & $\begin{array}{c}3.514^{* * *} \\
(0.977)\end{array}$ \\
\hline SSM Banks Clearing Members * EURO & $\begin{array}{c}3.595^{* * *} \\
(0.268)\end{array}$ \\
\hline Other Banks Clearing Members & $\begin{array}{c}4.257^{* * *} \\
(1.096)\end{array}$ \\
\hline Other Banks Clearing Members * EURO & $\begin{array}{c}0.685 \\
(0.561)\end{array}$ \\
\hline Other Banks Non-CM & $\begin{array}{c}3.105^{* * *} \\
(1.031)\end{array}$ \\
\hline Non-Banks Clearing Members & $\begin{array}{c}4.686^{* * *} \\
(1.435)\end{array}$ \\
\hline Non-Banks Clearing Members * EURO & $\begin{array}{c}0.884 \\
(1.130)\end{array}$ \\
\hline Non-Banks Non-CM & $\begin{array}{c}0.976 \\
(0.935)\end{array}$ \\
\hline Constant & $\begin{array}{c}18.18^{* * *} \\
(0.785)\end{array}$ \\
\hline $\begin{array}{c}\text { Observations } \\
\text { R-squared }\end{array}$ & $\begin{array}{c}813 \\
0.139\end{array}$ \\
\hline
\end{tabular}




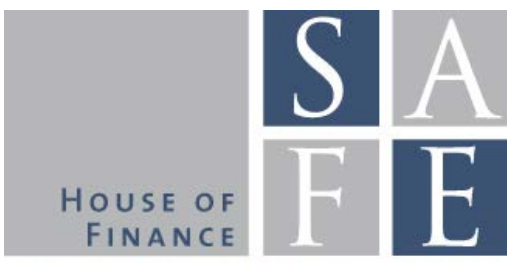

WORKING PAPER SERIES

\section{Recent Issues}

No. 254 Martin R. Goetz

No. 253 Thomas Johann, Talis Putnins, Satchit Sagade, Christian Westheide

No. 252 Nicole Branger, Patrick Konermann, Christian Schlag

No. 251 Wenhui Li, Christian Wilde

No. 250 Nathanael Vellekoop, Mirko Wiederholt

No. 249 Yuri Pettinicchi, Nathanael Vellekoop

No. 248 Jasmin Gider, Simon N. M. Schmickler, Christian Westheide

No. 247 Mario Bellia, Loriana Pelizzon, Marti G. Subrahmanyam, Jun Uno, Draya Yuferova

No. 246 Reint Gropp, Felix Noth, Ulrich Schüwer

No. 245 Charline Uhr, Steffen Meyer, Andreas Hackethal

No. 244 Mauro Bernardi, Michele Costola

No. 243 Nicoletta Berardi, Marie Lalanne, Paul Seabright
Financing Conditions and Toxic Emissions

Quasi-Dark Trading: The Effects of Banning Dark Pools in a World of Many Alternatives

Optimists and Pessimists in (In)Complete Markets

Belief Formation and Belief Updating under Ambiguity: Evidence from Experiments

Inflation Expectations and Choices of Households

Job Loss Expectations, Durable Consumption and Household Finances: Evidence from Linked Survey Data

High-Frequency Trading and Price Informativeness

Paying for Market Liquidity: Competition and Incentives

What Drives Banks' Geographic Expansion? The Role of Locally Non-Diversifiable Risk

Smoking Hot Portfolios? Self-Control and Investor Decisions

High-Dimensional Sparse Financial Networks through a Regularised Regression Model

Professional Networks and their Coevolution with Executive Careers: Evidence from North America and Europe 